\title{
CAMA
}

Centre for Applied Macroeconomic Analysis

\section{Effects of Oil Price and Global Demand Shocks on Small Island Developing States}

\section{CAMA Working Paper 67/2016 November 2016}

\author{
Alrick Campbell \\ Crawford School of Public Policy, ANU and \\ Centre for Applied Macroeconomic Analysis, ANU
}

\begin{abstract}
I employ a global VAR framework for 25 SIDS using annual data over the period 1980 to 2015. A key innovation associated with this research is the use of remittance weights to capture the close financial linkages between SIDS and advanced economies such as the US. I find that oil price shocks do not have a statistically significant negative effect on economic growth in most individual countries and different regions. Economies that are oil-intensive perform better than their low-intensity counterparts, but economic growth is likely to be greater if economies transition towards a more diversified energy supply mix. In terms of a negative demand shock to US GDP, output in SIDS decline more for those regions that have close economic ties with the US and are within its geographical proximity. From a policy standpoint, these results highlight the importance of gearing policy towards energy diversification and designing outward-oriented economic policies to guard against future oil price shocks.
\end{abstract}




\title{
Keywords
}

Global VAR (GVAR), Impulse Responses, Oil prices, Small Island Developing States

\author{
JEL Classification
}

Address for correspondence:

(E) cama.admin@anu.edu.au

ISSN 2206-0332

The Centre for Applied Macroeconomic Analysis in the Crawford School of Public Policy has been established to build strong links between professional macroeconomists. It provides a forum for quality macroeconomic research and discussion of policy issues between academia, government and the private sector.

The Crawford School of Public Policy is the Australian National University's public policy school, serving and influencing Australia, Asia and the Pacific through advanced policy research, graduate and executive education, and policy impact. 


\title{
Effects of Oil Price and Global Demand Shocks on Small Island Developing States
}

\author{
ALRICK CAMPBELL ${ }^{1}$
}

November 11, 2016

\begin{abstract}
I employ a global VAR framework for 25 SIDS using annual data over the period 1980 to 2015. A key innovation associated with this research is the use of remittance weights to capture the close financial linkages between SIDS and advanced economies such as the US. I find that oil price shocks do not have a statistically significant negative effect on economic growth in most individual countries and different regions. Economies that are oil-intensive perform better than their low-intensity counterparts, but economic growth is likely to be greater if economies transition towards a more diversified energy supply mix. In terms of a negative demand shock to US GDP, output in SIDS decline more for those regions that have close economic ties with the US and are within its geographical proximity. From a policy standpoint, these results highlight the importance of gearing policy towards energy diversification and designing outward-oriented economic policies to guard against future oil price shocks.
\end{abstract}

Keywords: Global VAR (GVAR); Impulse Responses; Oil prices; Small Island Developing States

\footnotetext{
${ }^{1}$ Crawford School of Public Policy, The Australian National University, 132 Lennox Crossing, Acton, ACT 2601, Australia. Email: alrick.campbell@anu.edu.au.
} 


\section{Introduction}

Most Small Island Developing States (SIDS) rely solely on fossil fuel imports to meet their domestic energy needs. On average, the value of oil imports accounts for approximately 35\% of US dollar denominated GDP in SIDS, almost 12 times the share of GDP in other major economies such as the US, UK, China, and Japan. For this reason, an understanding of output response to oil price movements is necessary for the design of appropriate policies to absorb external shocks. Existing literature generally ascribes to the view that exogenous oil price shocks are likely to have a disproportionately greater impact on economic activity in smaller states than larger ones, as well as economies with limited energy diversification; see for example (Finn (2000); Ghali and El-Sakka (2004); Blanchard and Gali (2007)). This view builds on the initial argument of Briguglio (1995) who finds that in addition to their dependence on fossil fuel imports, SIDS tend to be more vulnerable to external shocks because of their small size and inability exploit economies of scale, remoteness leading to high transport costs, and narrow export base.

SIDS have become more integrated into the world economy and it is important to analyze external shocks to the domestic economy from a global perspective. Specifically, I investigate the impact of oil price shocks and negative demand shocks in the US on economic activity in SIDS and analyze whether differences in effects depend on the level of energy diversification and energy intensity. Considering the dominant role of the US in the world economy, shocks originating from the US can be considered as global demand shocks. To overcome the limitations of the standard VAR methodology, I use the Global VAR (GVAR) framework proposed by Pesaran, Schuermann, and Weiner (2004) which incorporates a large number of variables and countries as well as bilateral remittance linkages among them. The GVAR methodology has been used to analyze the transmission of shocks to various economies and regions throughout the world. For example, Mohaddes, Raissi, and Raissi (2012) used it to analyze growth spillovers from the Gulf Cooperation Council (GCC) region to Middle East and North Africa (MENA) countries; Dees, Mauro, Pesaran, and Smith (2007) looked at how shocks to the US economy affect the Euro area while the impact of oil 
price shocks have been explored by Cashin, Mohaddes, Raissi, and Raissi (2014), Feldkircher (2014), and Allegret, Mignon, and Sallenave (2015).

I contribute to the body of work on the impact of oil price shocks by extending the emerging literature in a number of directions. First, unlike the majority of researchers who look at developed economies, I focus on SIDS spread over three regional blocs: the Caribbean; Pacific; and Africa, Indian Ocean, Mediterranean and South China Sea (AIMS). With the exception of the net oil-exporter, Trinidad and Tobago, these countries are largely service-based economies that are often dependent on tourism. Secondly, in contrast to Jayaraman and Choong (2009) who use a time series approach to analyze the causal relationship between GDP and the price of oil for four Pacific Island countries (PICS) over 1980-2007, I use a more integrated model that incorporates a larger set of countries, a longer time span, and accounts for bilateral financial linkages among countries. This is the first study to use remittance weights in a GVAR model to capture the close financial linkages between SIDS and the US economy.

The general findings from the GVAR, covering the period 1980 to 2015, reveal that global oil price shocks have very small and largely insignificant effects on individual SIDS and regions suggesting that these economies are more often than not resilient to external shocks of this nature. Furthermore, oil-intensive SIDS perform better than their low-intensity counterparts, but economic growth is likely to be greater if economies transition towards a more diversified energy supply mix. Additional results reveal that a negative US GDP shock dampens output more in regions that have closer economic ties with the US and are within its geographical proximity.

The paper consists of five main sections. Section 2 delves briefly into the literature while the data set used is discussed in Section 3. The empirical methodology is elaborated in Section 4 and the results reported and discussed in Section 5. The main conclusions drawn from the study are highlighted in Section 6. 


\section{Oil, energy and macroeconomic performance}

\subsection{Exogenous oil price shocks and economic fluctuations}

The literature on the relationship between oil prices and GDP has evolved considerably since the 1970s. The linear negative relationship between oil prices and aggregate measures of output was first elaborated in Rasche and Tatom (1977). The focus later shifted to the study of asymmetric effects as it became apparent that the linear relationship has changed since the 1980s. This strand of the literature began with Mork (1989) and was later extended by Hamilton (2003). The essence of their arguments is that economic activity responded to oil price increases, but was largely insignificant when oil prices declined. The focus has shifted recently with oil price shocks being distinguished by virtue of their origin. The emerging consensus is that oil prices are not only determined by supply-side factors but also driven by demand conditions (see Lippi and Nobili (2008); Kilian (2009); Hamilton (2009); Peersman and Van Robays (2012)).

Another strand of literature such as Blanchard and Gali (2007) argue that the effects of oil prices have been declining over time owing to improvements in monetary policy, flexible labour markets, and a smaller share of oil in productive activity. According to their results, a 10 per cent oil price shock would have reduced GDP in the United States by 0.7 per cent prior to 1984 but this later declined to 0.25 per cent over a two to three-year period. This argument, though applicable to economies that are dependent on oil imports, have not spawned a great deal of research in SIDS.

A key similarity of the studies discussed above is that they are largely concentrated in developed countries. In shifting the focus to net oil-importing developing countries, Van Hoa (1992) believes that the effects of price shocks can be more detrimental in limited resource-endowed economies given that the cost of energy represents a much larger proportion of GDP relative to more advanced economies. Finn (2000) argues that an energy price shock will cause GDP to decline much more than suggested by the energy expenditure share of GDP. Other arguments posit that there is likely to be very little effect on economic activity if the cost of energy represents a small proportion of GDP 
(Ghali \& El-Sakka, 2004). The evidence by Anciaes (2012) shows that energy as proportion of GDP ranges from 1.7 per cent to 2.3 per cent in the EU, US, China, and Japan, but this proportion is typically much larger in SIDS and therefore makes it very difficult to justify the presence of negligible impacts. For example, in 2010, the value of oil imports were approximately 6.7 per cent of GDP in Barbados and 12 per cent in Jamaica (International Monetary Fund, 2012). In light of these figures, higher oil intensity is likely to result in larger fluctuations in GDP growth in small open economies.

However, building on an earlier argument by Krugman (1983), Helbling et al. (2011) and Rasmussen and Roitman (2011) seem to be challenging these views by recognizing the importance of wealth effects and gain sharing in mitigating the impact of oil price shocks. For instance, Rasmussen and Roitman (2011) find that oil price shocks appear less costly for oil-importing countries due to the recycling of oil rents by oil exporters. The premise of their argument is that even though higher oil prices increase the import bill and transfer wealth from oilimporting countries to oil exporters, its effects on oil importers are partially offset by increases in external receipts. For most SIDS, external receipts are largely in the form of foreign aid, tourism, and remittances. Therefore, the overall impact on economic activity will depend on the degree of oil import dependence and the spending behavior of oil exporters. Furthermore, a downturn in economic activity in the US can minimize the extent to which small states benefit from these foreign exchange inflows. In general, the above arguments imply that we should let the data reveal the exact response of domestic output in SIDS to an exogenous oil price shock since the over-reliance on theory can produce ambiguous answers.

\subsection{Stylised facts and exploratory analysis}

Before discussing the impact of oil price shocks in more detail, it would be instructive to first provide some evidence on the oil-GDP relationship from a series of preliminary analyses. To do this, I decompose oil prices and real output into their trend and cyclical components to capture short-term fluctuations in the time series, and calculate correlation coefficient in each country between the 
cyclical components over the period 1980-2013. The long-run trend component of oil prices and GDP is estimated using the Hodrick-Prescott filter with a smoothing parameter of 100 for annual data series. In 70 per cent of the countries shown in Figure 1, positive values of the oil price cycle are associated with positive values of the real GDP cycle and vice-versa. It is not surprising that the countries that exhibit the highest levels of correlation are Trinidad and Tobago and Bahrain. Both economies are highly dependent on revenue from oil exports. For the Caribbean countries Haiti and Dominica, the correlation coefficients are negative, suggesting that these countries are likely to be less resilient to oil price shocks. Overall, these early results do indicate that oil price shocks may not necessarily have a negative effect on oil-intensive small open economies.

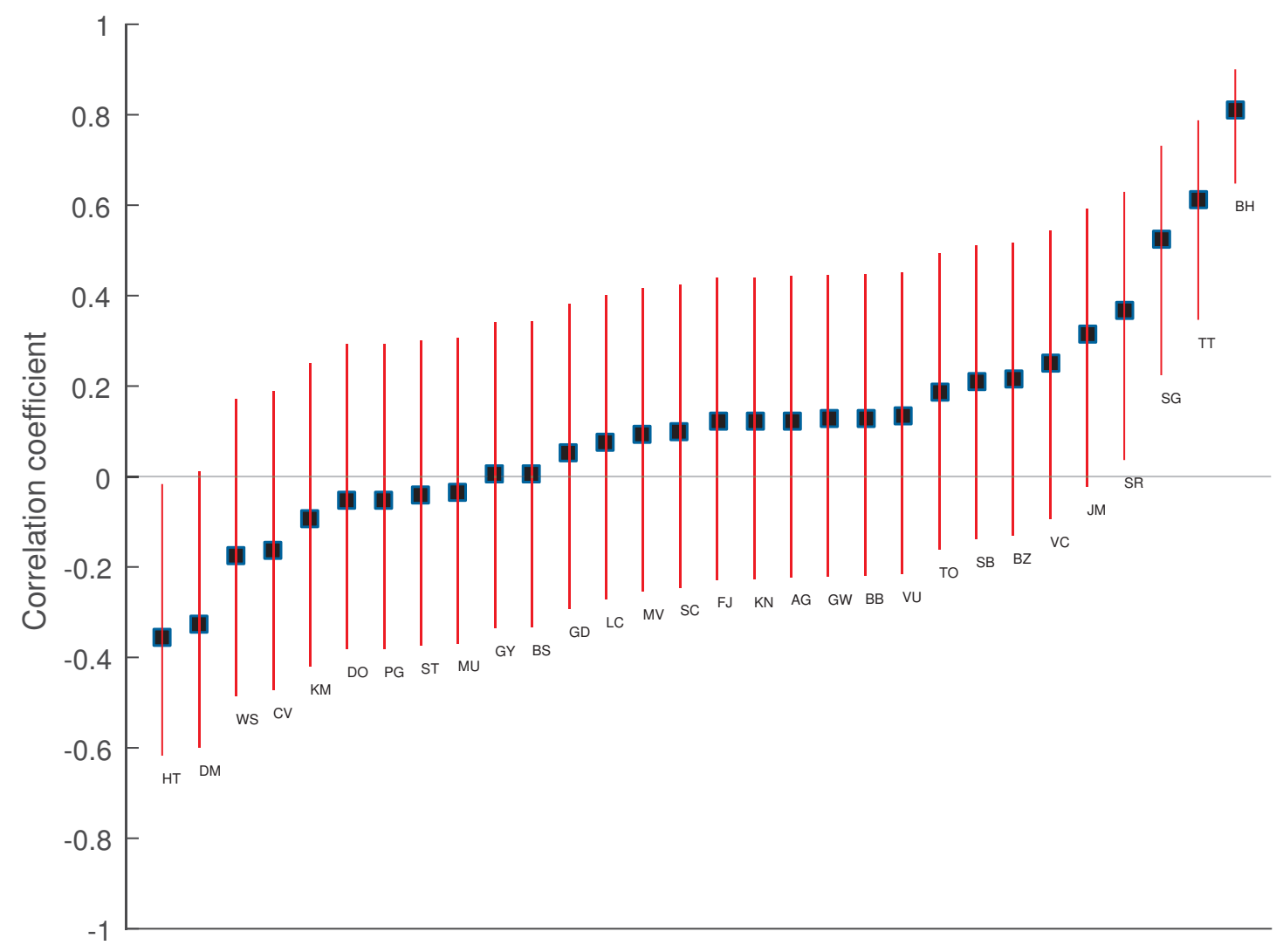

Figure 1: Correlation between Oil Price and GDP cyclical components in 30 SIDS member countries with 95\% confidence interval, 1980-2013. The cyclical components have been estimated by using the Hodrick-Prescott filter with a smoothing parameter of 100 for annual data series. 
Next, I compare the trend in oil intensity for all SIDS combined with that of a few major economies over the period 1980 to 2013. This analysis is based on the argument of Van Hoa (1992) who argues that oil price shocks have a greater impact on the economy when it is more dependent on oil. The evidence in Figure 2 shows that oil consumption represents only about 3\% of GDP in the larger economies. However, for SIDS, oil-use intensity has risen sharply since the late 1990s and now accounts for approximately 35\% of GDP despite the impact of the 2007-2008 financial crisis. In contrast to the evidence in Figure 1, this implies that oil price changes should generate large fluctuations in the real output of SIDS.

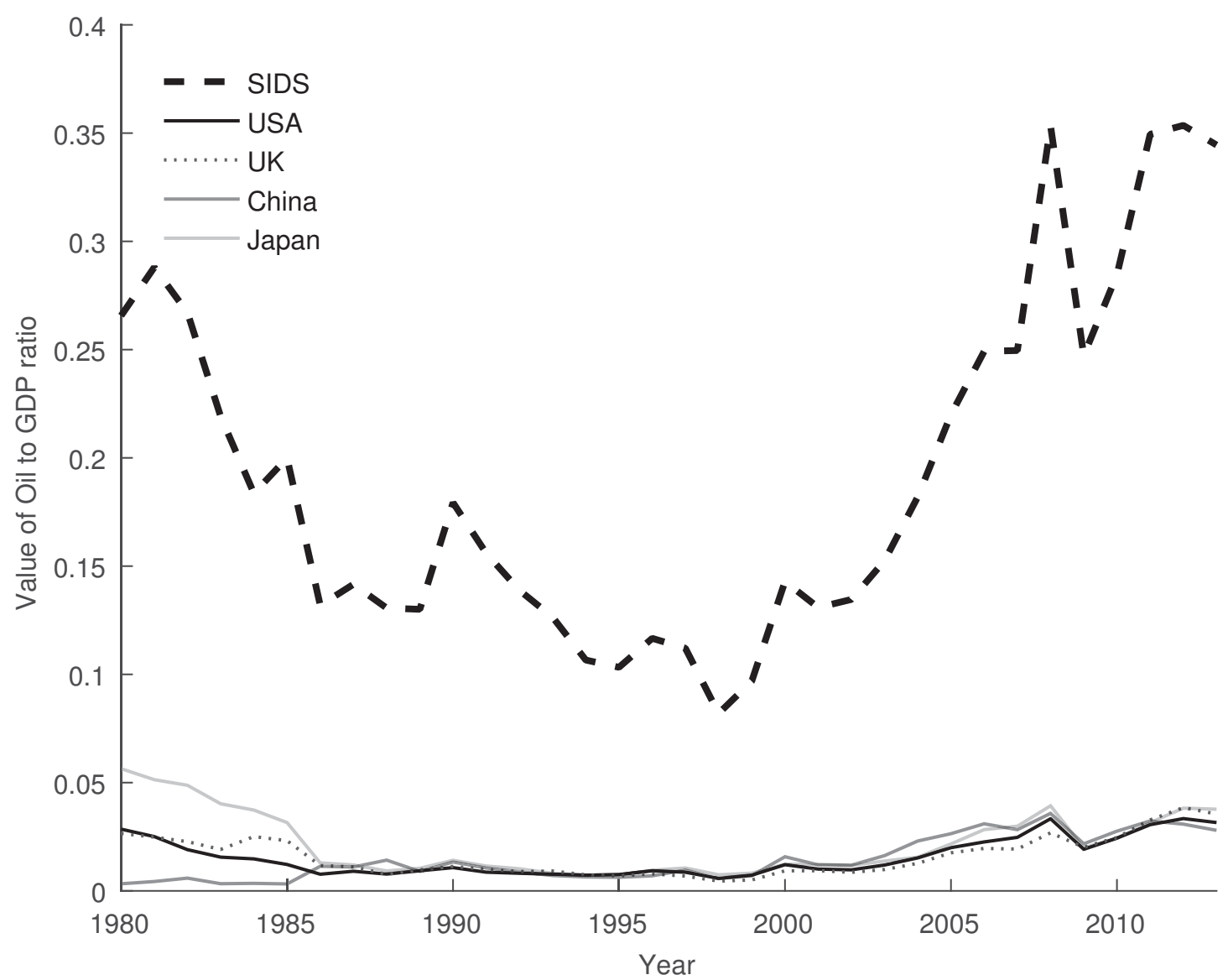

Figure 2: Trend in oil intensity for sample of countries: 1980-2013. The ratios are based on the total value of crude oil consumption relative to total GDP in nominal US dollars for 27 SIDS for which data are available.

Though many SIDS are largely service-based economies with tourism alone 
accounting for more than 20 per cent of GDP according to Denman, Denman, and Scott (2012), there has been no noticeable downward trend in oil intensity for most of the countries. The absence of reduced oil intensity could be due to the limited diversification of the energy mix and my final analysis in Figure 3 illustrates this point. It plots the percentage change in the share of oil in the energy mix against the percentage change in energy intensity for 42 SIDS. Values above zero indicate an increase in oil share or energy intensity. More than $50 \%$ of SIDS continue to use oil as their sole source of energy or have become more reliant on oil compared to 1980. Similarly, most SIDS are now using more energy to produce each unit of GDP compared to 1980.

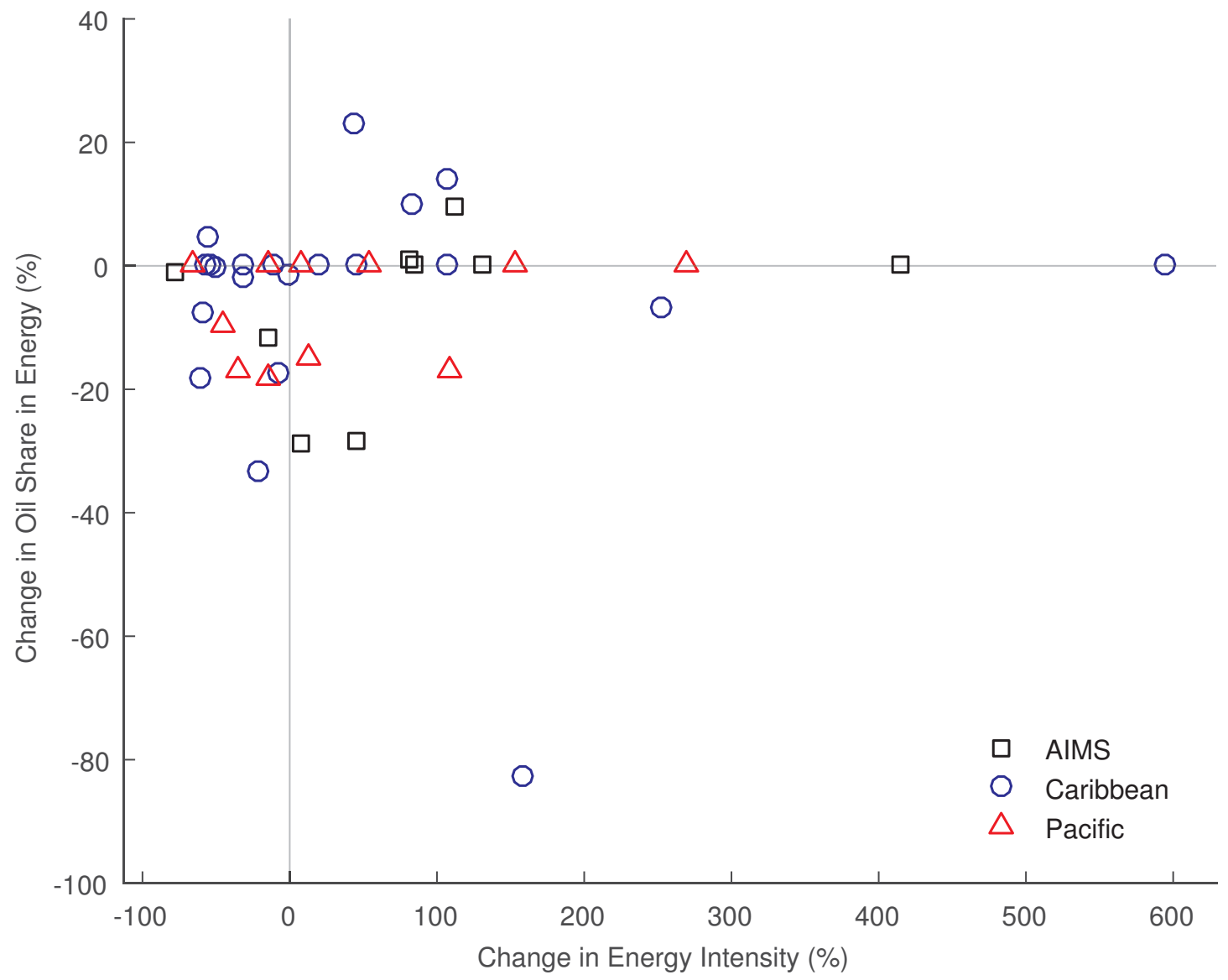

Figure 3: Evolution of Oil and Energy importance between 1980 and 2011 for 42 SIDS.

Figure 3 is also divided into four quadrants to indicate how each country has performed relative to each other. The top-left quadrant captures those 
countries with increased oil share and reduced energy intensity. Suriname is the only country in the sample that is located in this quadrant. The top-right quadrant shows that a few countries have become more oil and energy dependent. This contrasts with a larger group of countries in the bottom quadrants, which experienced some degree of substitution. Specifically, the net oil-exporting country of Trinidad and Tobago became less oil-intensive but more energyintensive. Trinidad and Tobago possesses significant reserves of natural gas and exports the majority of its refined crude oil. Countries such as Fiji and Jamaica which are located in the bottom-left quadrant have seen a considerable drop in oil share and energy intensity.

Even though the above results produce some interesting insights, it is difficult to assess the vulnerability of SIDS to oil price shocks using such a simple cursory analysis. The next section discusses the data that form the basis of a detailed investigation of the effect of oil price shocks and their associated transmission channels on real output in SIDS.

\section{Data}

To examine how oil price shocks affect SIDS, quarterly data of good quality would be ideal, but this is scarce. Therefore, I employ an annual panel data series spanning 26 countries (25 SIDS and the US) over the period 1980 to 2015. Despite the small number of observations for each country, this series represents the best and longest available dataset from which we can analyse how global developments affect macroeconomic performance in SIDS. Excluding the economy of the US, countries are divided into three distinct geographical regions: the Caribbean, the Pacific and the Atlantic, Indian Ocean, Mediterranean and South China Sea (AIMS). The list of countries in regional blocks are shown in Appendix A.1 and are defined according to the UN Department of Economic and Social Affairs (2015). These countries represent almost 80 per cent of the United Nations member states under the SIDS classification.

The main variables covered in my analysis are real GDP $\left(y_{i t}\right)$ in local currency values, real effective exchange rate $\left(\right.$ reer $\left._{i t}\right)$, inflation rate $\left(\pi_{i t}\right)$, and oil price $\left(\right.$ poil $\left._{t}\right)$. Other variables include remittance flows measured in US dollars and 
GDP in current international dollars. In the preliminary exercise, I also included measures of oil intensity and energy mix diversification. Details related to the computation of variables and their data sources are available in Appendix A.

The $y_{i t}$ and poil $_{t}$ measures are included in the model since my main objective is to analyze how real output is affected by the oil price. The inclusion of the remaining variables $\pi_{i t}$ and reer $_{i t}$ is motivated by arguments about the two main channels through which oil price movements indirectly influence economic activity. On the supply side, rising oil prices feed directly into higher input costs and create upward pressure on the price of energy-intensive goods causing inflation. This lowers real income and causes rational consumers to reduce their consumption spending, resulting in lower aggregate demand (Finn, 2000; Hamilton, 2009; Kilian, 2008). The demand-side channel emphasizes that oil price increases lead to income transfers from countries that are net importers of oil to oil-exporting countries, which then depresses demand for non-tradables. However, the negative impact on domestic GDP could be partly offset by a real depreciation of the domestic currency if the price of tradables relative to nontradables rise by a bigger proportion than that of the oil-exporting country, and oil exporters spend their additional income in oil-importing countries (Ferderer, 1997; Rasmussen \& Roitman, 2011).

A brief description of the main variables in this study are presented in Table 1. Average real GDP shows mild variation among the countries over time. The oil price variable has the highest degree of variability followed by the real exchange rate. The inflation variable has the least variability across countries and over time with the inflation rate being highest in Suriname in the 1990s.

Table 1: Descriptive statistics for main variables included in the VAR analysis: 1981-2015

\begin{tabular}{lcccc}
\hline Variable & Mean & Maximum & Minimum & Std. Dev. \\
\hline Real GDP $(y)$ & 4.23 & 4.84 & 2.86 & 0.12 \\
Inflation rate $(\pi)$ & 0.08 & 0.89 & -0.39 & 0.06 \\
Real exchange rate $($ reer $)$ & 4.72 & 9.23 & 3.65 & 0.34 \\
Oil price $($ poil) & 3.45 & 4.72 & 2.54 & 0.67 \\
\hline
\end{tabular}

Notes: Except for oil price, summary statistics are pooled across countries and over time. The inflation rate is in log differences and all other variables are in log levels. 


\section{Econometric model}

Increasing economic linkages with the global economy and the openness of SIDS suggest that a common observed global shock such as changes in oil prices would have important spillover effects that necessitate an understanding of these links and the design of policy measures to mitigate their effects, where necessary. The GVAR modeling approach as developed by Dees et al. (2007) captures economic interdependencies in the global economy. The application in this paper is based on the Matlab GVAR Toolbox 2.0 provided by Smith and Galesi (2014). Each country is modeled separately using a VAR model, which are linked together using foreign-specific variables that are based on the remittance flows among the included countries. In addition, I include the United States (US) in the model to analyze how developments in a globally dominant economy transmit shocks to SIDS. Although the GVAR methodology can be applied to stationary and/or integrated variables, it relies on the assumption that the model has some weakly exogenous $I(1)$ variables and that the variables in the system are dynamically stable over time.

The model consists of a set of $N+1$ countries $i=0,1,2, . ., N$, with country 0 being the US, which I use as a reference country primarily because of its dominance in the world economy and in order to analyze how developments in a globally dominant economy transmit shocks to SIDS. Each country model, excluding the US, has a $\operatorname{VARX^{*}}\left(p_{i}, q_{i}\right)$ structure of the form:

$$
\begin{aligned}
x_{i, t}= & \alpha_{i, 0}+\alpha_{i, 1} t+\sum_{j=1}^{p_{i}} \Phi_{i, j} \mathrm{x}_{i, t-j}+ \\
& \sum_{j=0}^{q_{i}} \Lambda_{i, j} x_{i t t-j}^{*}+\sum_{j=0}^{q_{i}} \Psi_{i, j} d_{t-j}+u_{i, t}
\end{aligned}
$$

where $x_{i, t}=\left(y_{i, t}, \pi_{i, t}, \text { reer }_{i, t}\right)^{\prime}$, is a $k_{i} \times 1$ vector of endogenous domestic variables, $x_{i t}^{*}=\left(y_{i t}^{*}, \pi_{i t}^{*}, \text { reer }_{i t}^{*}\right)^{\prime}$, a $k_{i}^{*} \times 1$ vector of weakly exogenous country-specific foreign variables and a $m \times 1$ vector consisting of global variables $d_{t}=$ poil $_{t}$. The vectors of fixed intercepts $a_{i 0}$ and of deterministic time trend coefficients $a_{i 1}$ are both $k_{i} \times 1$; $\Phi_{i, j}, \Lambda_{i, j}$ and $\Psi_{i, j}$ are of dimension $k_{i} \times k_{i}, k_{i} \times k_{i}^{*}$ and $k_{i} \times m$, respectively; and 
$u_{i t}$ is a $k_{i} \times 1$ vector of idiosyncratic country-specific shocks that are serially uncorrelated with mean zero and a non-singular covariance matrix such that $u_{i t} \sim$ iid $\left(0, \sum_{i i}\right)$. Also, $p_{i}, q_{i}, k_{i}$, and $k_{i}^{*}$ need not be the same for all countries.

The reer $_{i t}$ variable is not included in the model for the US. Similar to Pesaran et al. (2004), I also treat poil $t$ as endogenous in the US model and weakly exogenous in all SIDS models. The country-specific foreign variables are constructed using fixed weights $w_{i j}$ based on bilateral remittance data. Computation method and reported weights are available in Appendix A.3. Hence, the vector of foreign-specific variables in $x_{i, t}^{*}$ are given by:

$$
y_{i t}^{*}=\sum_{j=0}^{N} w_{i j}^{y} y_{i t} ; \pi_{i t}^{*}=\sum_{j=0}^{N} w_{i j}^{\pi} \pi_{i t} ; \text { reer }_{i t}^{*}=\sum_{j=0}^{N} w_{i j}^{\text {reer }} \text { reer }_{i t}
$$

With the exception of the US, all country models treat the foreign-specific variables $\pi_{i t}^{*}$ and $y_{i t}^{*}$ as weakly exogenous. Since most countries usually peg their currency to the US dollar, I follow Pesaran (2004) and exclude the foreignspecific variable reer $_{i t}^{*}$ for all SIDS since it is generally strongly correlated with its endogenous counterpart. The US model is the only one that includes the foreign-specific variable reer $_{i t}^{*}$ as weakly exogenous. The specific setup for the individual SIDS and the US economy can be seen in Appendix A.

Furthermore, to allow for the possibility that some or all of the variables have unit roots and there is cointegration, the individual country VARX models in 1 are estimated in error correction form given by:

$$
\Delta x_{i, t}=c_{i, 0}+a_{i} \beta_{i}^{\prime} \varsigma_{i, t-1}+\Lambda_{i, 0} \Delta x_{i, t}^{*}+\sum_{j=1}^{p_{i}-1} \Gamma_{i, j} \Delta \mathrm{z}_{t-j}+\sum_{j=0}^{q_{i}-1} \Psi_{i, j} \Delta d_{t-j}+u_{i, t}
$$

where $z_{i, t}=\left(x_{i, t}^{\prime}, x_{i, t}^{*^{\prime}}\right)^{\prime}, \varsigma_{i, t}=\left(z_{i, t}^{\prime}, d_{t}^{\prime}, t\right)^{\prime}, a_{i}$ is a $k_{i} \times r_{i}$ matrix of rank $r_{i}$ and ${ }_{i}$ is a $\left(k_{i}+k_{i}^{*}+m_{d}\right) \times r_{i}$ matrix of rank $r_{i}$. By partitioning $\beta_{i}$ as $\beta_{i}=\left(\beta_{i, x^{\prime}}^{\prime}, \beta_{i, x^{*}}^{\prime}, \beta_{i, d}^{\prime}, \beta_{i, t}^{\prime}\right)^{\prime}$ conformable to $\varsigma_{i, t}=\left(z_{i, t}^{\prime}, d_{t}^{\prime}, t\right)^{\prime}$, the $r_{i}$ error correction terms defined by 3 are rewritten as $\beta_{i}^{\prime} s_{i, t-1}=\beta_{i, x}^{\prime} x_{i, t-1}+\beta_{i, x^{*}}^{\prime} x_{i, t-1}^{*}+\beta_{i, d}^{\prime} d_{t-1}+\beta_{i, t}^{\prime}(t-1)$ which shows that cointegration is possible both within $x_{i, t}$ and between $x_{i, t}$ and $x_{i, t}^{*}$, and 
consequently across $x_{i, t}$ and $x_{j, t}$ for $i \neq j$.

After estimating all the coefficients in 3 for each country, I transform them to obtain all the coefficient estimates in the original VARX ${ }^{*}$ models in 1 . Written in lag operator form, the VARX model in 1 is:

$$
\Phi_{i}\left(L, p_{i}\right) x_{i, t}=a_{i, 0}+a_{i, 1} t+\Lambda_{i}\left(L, q_{i}\right) x_{i, t}^{*}+\Psi_{i}\left(L, q_{i}\right) d_{t}+u_{i, t}
$$

where $\Phi_{i}\left(L, p_{i}\right)=I-\sum_{j=1}^{p_{i}} \Phi_{i, j} L^{j}, \Lambda_{i}\left(L, q_{i}\right)=\sum_{j=0}^{q_{i}} \Lambda_{i, j} L^{j}$ and $\Psi_{i}\left(L, q_{i}\right)=\sum_{j=0}^{q_{i}} i, j L^{j}$ are the matrix lag polynomial of the coefficients associated with the domestic, foreign and global variables. Furthermore, since $z_{i, t}=\left(x_{i, t}^{\prime}, x_{i, t}^{x^{\prime}}\right)^{\prime}, 4$ becomes:

$$
\mathrm{A}_{i}\left(L, p_{i}, q_{i}\right) z_{i, t}=a_{i, 0}+a_{i, 1} t+\Psi_{i}\left(L, q_{i}\right) d_{t}+u_{i, t}
$$

where $\mathrm{A}_{i}\left(L, p_{i}, q_{i}\right)$ is defined as $\mathrm{A}_{i}\left(L, p_{i}, q_{i}\right)=\left[\Phi_{i}\left(L, p_{i}\right),-\Lambda_{i}\left(L, q_{i}\right)\right]$ so that it is conformable to $z_{i, t}=\left(x_{i, t}^{\prime}, x_{i, t}^{*^{\prime}}\right)^{\prime}$.

Following this, the GVAR model is solved simultaneously by linking the variables $z_{i t}$ with all the $k=\sum_{i=0}^{N} k_{i}$ endogenous variables of the global model which are collected in the $k \times 1$ vector $x_{t}=\left(x_{0 t}^{\prime}, x_{1 t}^{\prime}, \ldots, x_{N t}^{\prime}\right)^{\prime}$ using:

$$
z_{i t}=W_{i} x_{t}
$$

where $W_{i}$ has a $k_{i} \times k$ dimension defined by the remittance weights matrix.

Even though $p_{i}$ and $q_{i}$ can vary among each country, $\mathrm{A}_{i}(L, p)$ is constructed from $\mathrm{A}_{i}\left(L, p_{i}, q_{i}\right)$ by setting $p=\max \left(p_{0}, p_{1}, \ldots, p_{N}, q_{0}, q_{1}, \ldots, q_{N}\right)$ and augmenting the $p-p_{i}$ or the $p-q_{i}$ additional terms in the power of the lag operator by zeros. Given Equation 6, stacking the $N+1$ individual country models yields the GVAR(p) model:

$$
G(L, p) x_{t}=\varphi_{t}
$$




$$
\begin{gathered}
\text { where } G(L, p)=\left(\begin{array}{c}
\mathrm{A}_{0}(L, p) W_{0} \\
\mathrm{~A}_{1}(L, p) W_{1} \\
\vdots \\
\mathrm{A}_{N}(L, p) W_{N}
\end{array}\right) \\
\text { and } \varphi_{i t}=\left(\begin{array}{c}
a_{00}+a_{01} t+\Psi_{0}(L, p) d_{t}+u_{0 t} \\
a_{10}+a_{11} t+\Psi_{1}(L, p) d_{t}+u_{1 t} \\
\vdots \\
a_{N 0}+a_{N 1} t+\Psi_{N}(L, p) d_{t}+u_{N t}
\end{array}\right)
\end{gathered}
$$

The GVAR(p) model has a recursive structure that can be conveniently used to carry out generalized impulse response function (GIRF) analysis to track the responses of variables in the system to global shocks. I focus on GIRFs since it is invariant to the ordering of variables in the model. Orthogonalization of the shocks may not be necessary if there is possible correlation of the various shocks among countries. However, Kim (2013) finds that GIRF analysis is an extreme case of identification and may produce misleading results. To lend support to the GIRF outcomes, I use orthogonalised impulse response function (OIRF) analysis to show that the results are similar for both methods. A more detailed exposition of both approaches with additional results are available in Appendix C.

The model proposed in this paper relies on a number of assumptions that need to be tested. These tests focus on the order of integration, appropriate lag structure, cointegration rank, weak exogeneity, and stability of the individual models over time. In general, most variables are integrated of order 1 , with 1 or 2 possible long-run relations identified among them. Except for three cases, the null of weak exogeneity was not rejected. Furthermore, the stability tests showed that the estimated GVAR model is dynamically stable. All performed tests are described and discussed in more detail in Appendix B. 


\section{Results and discussion}

In this section I examine three scenarios to gauge the reaction of the real economy for SIDS to exogenous shocks. I first show output response to exogenous oil price shocks and then focus on the effects of a slowdown in the US economy. Finally, I explore differences in output response based on the proportion of oil in the energy mix and energy intensity use.

\subsection{Shock to global oil prices}

As oil price increases lead to income transfers from countries that are net importers of oil to oil-exporting countries, real output is expected to contract over time while increasing for oil exporters. Figure 4 presents the GIRFs of a positive one standard error shock to oil prices which corresponds to an increase of about 21 per cent in the price of oil each year. It shows the results for individual countries and how they compare to the regional average. Overall, 8 out of 25 SIDS have negative average output effects, but this was less than 1 per cent in most cases. In terms of average responses (see bottom-right panel of Figure 4) for SIDS as a group, the shock to oil prices showed that the average median response of GDP (1.2\%) is small and positive but this is not statistically different from zero.

For Caribbean countries, oil price increases do not appear to have any significant negative impact on output except for in countries such as Belize which experiences a decline over time and St. Kitts and Nevis which sees a fall in output within the first year. On the contrary, Trinidad and Tobago being the only oil exporter experiences a significant and positive long-run effect on GDP (3.4\%) as expected. Output also increases for Jamaica but significant effects were observed only in the first year.

The Pacific islands were the most affected by oil price shocks. The long-run effects stand out more clearly for Fiji and Papua New Guinea which both had average output declines of $0.9 \%$ and $1.2 \%$, respectively. The shocks do not appear to have much of an impact in Samoa, Solomon Islands, or Tonga. Unexpectedly, a significant and positive output response was observed for Vanuatu over the 
period.

As a group, the AIMS region had the smallest output response on average following an oil price shock $(0.3 \%)$. However, the results were mixed for individual countries in this group. For example, significant positive average effects are observed for Cabo Verde (1.5\%) and São Tomé and Príncipe (3.6\%) respectively, while oil price shocks appear to have only a modest effect on real GDP for other oil importers in the region.

The above findings support recent evidence in the literature that focus on oilimporting countries and finds negligible oil price effects on output. For example, Rasmussen and Roitman (2011) reveal that with the exception of the United States, oil price shocks do not result in contemporaneous declines in output in many oil-importing countries. They argue that even though oil price increases transfer income from oil-importing countries to oil-exporting economies, the resulting reduction in domestic demand is partly offset by export demand or other international flows from the foreign recipients of the income transfer. A similar argument by Helbling et al. (2011) shows that a reduction in oil supply growth that causes an oil price hike does not lead to major output loss over the long run.

\subsection{Negative shock to US real GDP}

Since many SIDS are dependent on advanced economies such as the US for foreign exchange inflows, I also consider the impact of a negative GDP shock to US GDP - a global demand shock - and examine how it transmits to individual economies and the region as a whole. As the recent global financial crisis has shown, many economies are very sensitive to developments in the US economy. Therefore, dependence on external demand from the US should see SIDS economies reacting strongly to declines in US GDP.

The time profile of the impulse responses related to the negative one standard error shock to US GDP are displayed in Figure 5. In the US, this approximates to about a $1 \%$ decrease in GDP on an annual basis. Real output for the SIDS group falls by approximately $1 \%$ each year with statistically significant effects observed in some countries. In fact, with the exception of Belize, Papua New 
Guinea, Guinea-Bissau, and Guyana which experience positive but statistically insignificant effects; all countries have negative average median responses. If we look more closely at the regional averages in Figure 5 (bottom-right panel), GDP in the Caribbean fell the most compared to the other two regions $(-1.2 \%)$ in light of the stronger economic ties with the US through tourism, remittances, foreign direct investment, and official development assistance. The economy with the largest negative and significant output drop - Trinidad and Tobago $(-2.3 \%)$ - belong to this group.

AIMS, which is the most heterogeneous of the SIDS groups, had a lower output response over the long run $(-0.4 \%)$ than the Caribbean. I argue that their comparatively lower output losses may be due to their stronger economic ties with European and African economies. Of all the countries in this group, Cabo Verde sees the biggest fall in output $(-1.7 \%)$ following a negative US GDP shock. In general, even if AIMS economies do not have strong financial linkages with the US, they are likely to feel contagion effects since Europe also has strong economic ties with the US, and both economies are much more financially integrated. Therefore, it is possible that these effects are much larger than what is being suggested by the bilateral economic relations between AIMS and the US.

Compared to the Caribbean and AIMS groups, the effect on Pacific SIDS is more muted and marginally positive at $0.04 \%$, though the effect is not statistically significant. However, a larger deterioration in output $(-0.7 \%)$ is observed for Samoa. The smaller output response for the Pacific group may be the result of fostering greater economic ties with China which has been the main driver of global growth over the last decade. This region also benefits from remittance inflows from major source countries such as Australia and New Zealand, which have largely avoided the onslaught of recent global recessions.

In 2013, remittance inflows to several SIDS were close to $10 \%$ of GDP, accounting for as much as $15 \%$ in countries such as Jamaica. This foreign exchange flow has been used for human capital formation through spending on schooling for children (Amuedo-Dorantes, Pozo, \& Vargas-Silva, 2010) as well as the financing of business investments (Woodruff \& Zenteno, 2007).

As a group, SIDS experience declines in output, though the effect is not statistically significant. The overall evidence suggests that the effect of a negative 
shock to US output is strongest for those regions that have close economic ties with the US and are within its geographical proximity. This does not mean that Pacific Island states are insulated from these negative demand shocks since advanced economies such as Australia and New Zealand are strongly integrated with the US and can influence economic activity in Pacific countries. Therefore, depressed demand in the US could also see reduced foreign exchange outflows from Australia and New Zealand to Pacific Island economies.

\subsection{Energy diversification and energy intensity}

As a final exercise, I examine whether dissimilarities in output response for individual countries or groups could arise from differences in the proportion of oil in the energy mix and energy intensity despite the muted response of GDP to oil price shocks. This is in line with arguments by Blanchard and Gali (2007), Cologni and Manera (2009), Peersman and Van Robays (2012), and Anciaes (2012) who suggest that countries with a higher energy intensity of production or higher oil share in their energy mix are likely to have stronger output responses following a negative oil price shock. To explore these differences, I separate the countries into a 'high and 'low' category by using the mean energy intensity and oil share as a cut-off point (see Appendix A for classification of countries). These results are presented in Figure 6 and do not appear to show any distinct differences among country groupings.

I begin by looking at differences in terms of energy intensity - energy consumed per unit of economic output. Contrary to expectations, these results show that output increases irrespective of whether economies are more or less energy intensive, but low energy-intensive economies do experience a smaller output increase in the long run $(0.9 \%)$ compared to more energy-intensive economies $(1.9 \%)$.

In terms of the share of oil in the energy mix, this was generally high with over 80 per cent of the countries in the sample relying on oil for at least 80 per cent of their domestic consumption needs. The impulse responses show that countries with a lower share of oil in the energy mix performed noticeably better than those countries with a less diversified energy mix, that is, $1.5 \%$ compared 
to $0.5 \%$. These general results suggest that positive growth outcomes are more likely for SIDS that combine increased energy intensity with transition towards a more diversified energy supply mix.

Despite the differences in terms of energy intensity and oil share, the generally positive output effects observed seems to be a reflection of the sectoral composition of these economies. The sectoral structure of small states have allowed many of them to harness their natural resource base by orienting economic activity towards labor-intensive and service-based activities in addition to their specialization in niche markets (Briguglio, Cordina, \& Kisanga, 2006). While tourism is the key component of the services industry in many states, countries such as Trinidad and Tobago have strengthened the importance of the financial services sector in an attempt to reduce its dependence on the energy sector. Financial services now account for approximately 11.5 per cent of domestic activity in that country (Tsikata, Moreira, \& Hamilton, 2009).

Other countries such as Fiji have developed niche markets in seaweed production. Encontre (n.d.) argues that economic diversification has been a contributing factor to economic stability in the context of exogenous shocks. In addition to tourism and financial services, this facilitates the need to develop comprehensive incentive programs to target service industries including information and communication technology, recreation, culture, and sports.

The sectoral structure of SIDS is also related to the subsistence nature of the economy and the ability to access land, and is seen as a contributory factor in alleviating the adverse effects of potentially limited economic growth performance. In the presence of external shocks, individuals gravitate towards subsistence agriculture to minimize the impact on their livelihood. BaylissSmith and Feachem's study (as cited in Yari (2003)) refers to this phenomenon as 'subsistence affluence'. The United Nations Economic and Social Commission for Asia and the Pacific (2003) argues that policies should be geared towards complementing the cash-based economy with improvements in the productivity of the subsistence sector. For these reasons and others, SIDS do not appear to be susceptible to the devastating impact of oil price shocks that is often touted in the literature. 

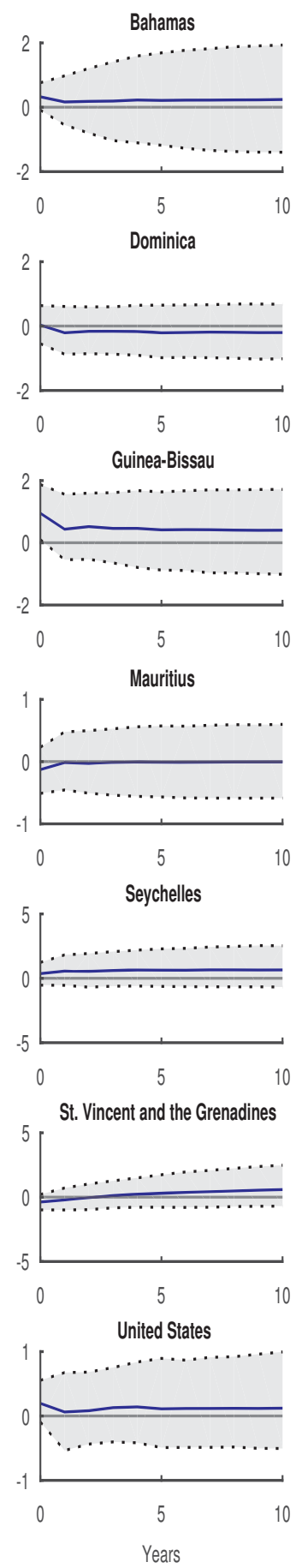
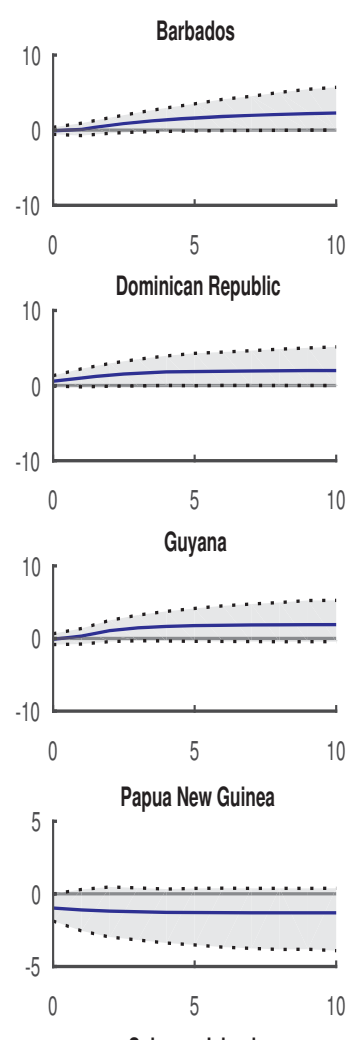

Solomon Islands
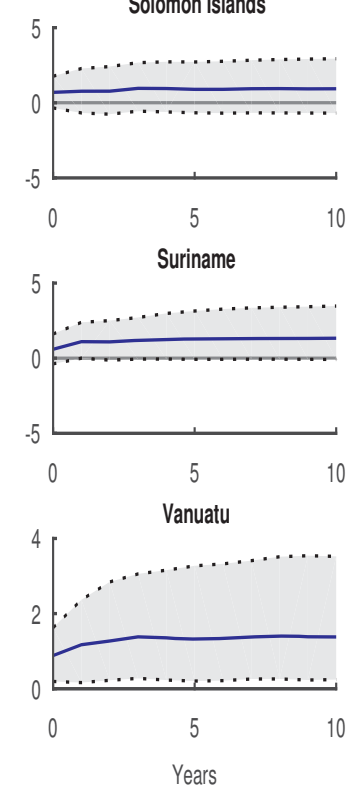
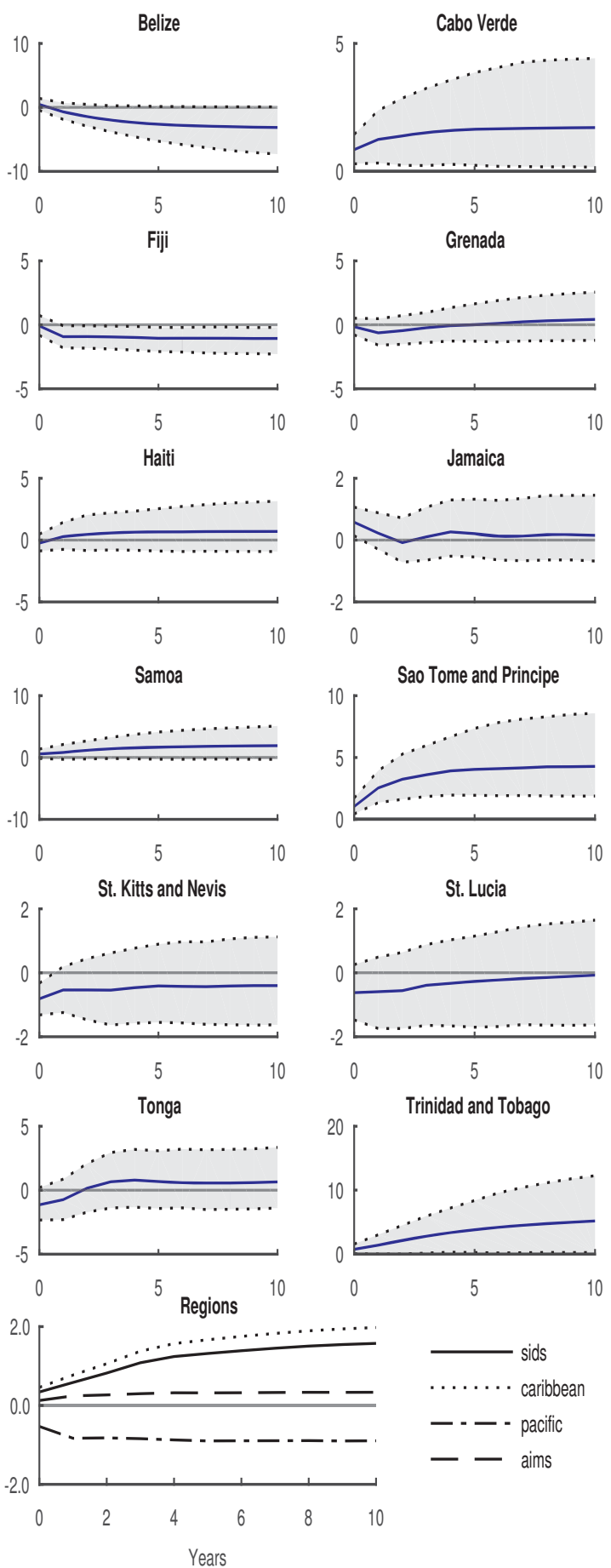

Figure 4: Median impulse response of GDP to a positive one standard error shock to oil prices. Solid grey lines represent the annual change (\%) in output for a given country or region in comparison to the regional aggregate (solid black line) and associated $95 \%$ confidence interval bands (thick dashed line). PPP-based GDP weights are used to calculate regional aggregates. 

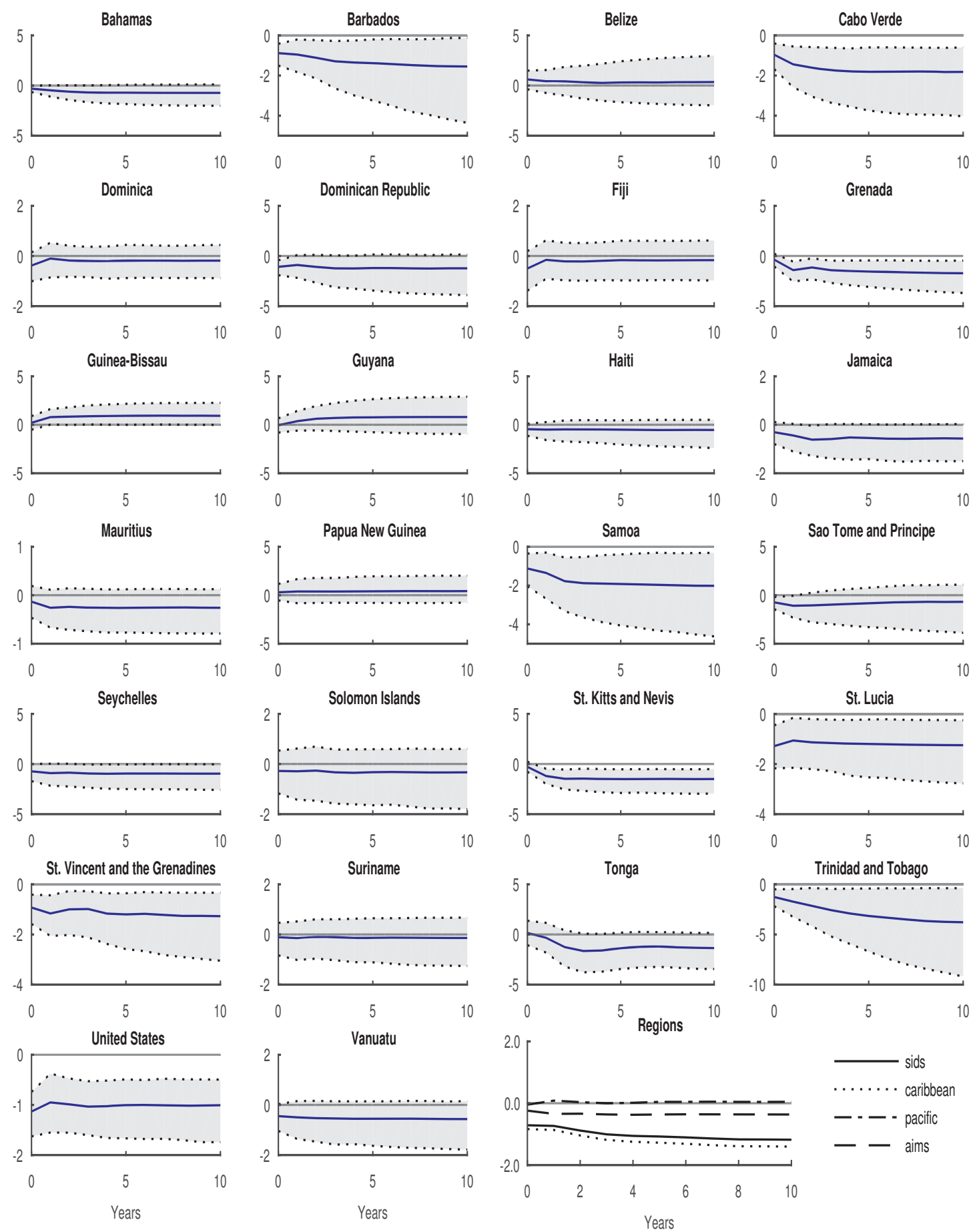

Figure 5: Median impulse response of GDP to a negative one standard error shock to US GDP. Solid grey lines represent the annual change (\%) in output for a given country or region in comparison to the regional aggregate (solid black line) and associated $95 \%$ confidence interval bands (thick dashed line). PPP-based GDP weights are used to calculate regional aggregates. 


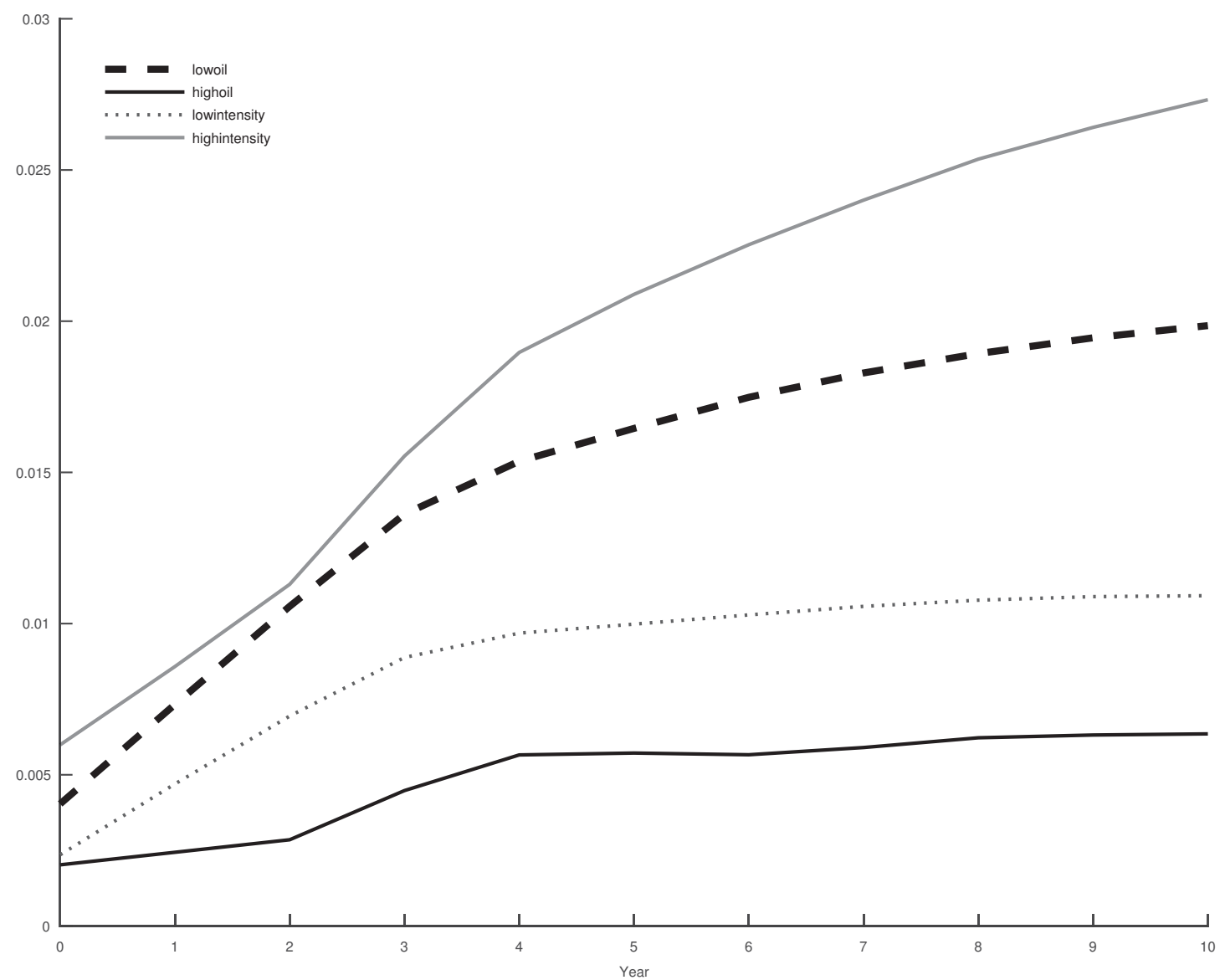

Figure 6: Median impulse response of GDP to a negative one standard error shock to oil price under different energy mix and energy intensity scenarios. PPP-based GDP weights are used to calculate group aggregates. 


\section{Concluding remarks}

Several studies show how oil price shocks affect developed and large developing countries, but work in this area is generally lacking for SIDS and this study tried to fill this gap. As oil use accounts for a significant proportion of GDP in most SIDS compared to many advanced economies, it is expected to result in significant adverse output effects in SIDS. Moreover, the impact on these economies is expected to be greater the less diversified they are in terms of energy use. However, the findings in this study contravene these long-established views.

To determine if SIDS are susceptible to oil price shocks, I use a Global Vector Autoregressive (GVAR) model, estimated with annual data from 1980 to 2015 and using remittance weights. I do this for a set of 25 SIDS grouped into three regions: AIMS, Caribbean, and the Pacific. Though individual economies such as Belize, Fiji, and St. Kitts and Nevis do show significant negative output responses, oil price shocks do not have a statistically significant negative effect on economic growth in most SIDS and different regions. This null finding of low output response is similar to Rasmussen and Roitman (2011), who find no contemporaneous decline in output for many oil-importing countries following an oil price increase. Additional results in this study also reveal that oil-intensive SIDS perform better than their low-intensity counterparts, but economic growth is likely to be greater if economies transition towards a more diversified energy supply mix.

As oil price shocks can affect SIDS economies indirectly, I also analyse the impact of a negative demand shock in the US on output in SIDS. An oil price shock that depresses economic activity in the US is likely to reduce foreign exchange inflows to SIDS. The overall evidence reveals that the effect of a negative shock to US output is strongest for those regions that have close economic ties with the US and are within its geographical proximity.

While I do not discount future oil price increases having a larger adverse economic impact on SIDS as global conditions continue to change, these results dispel the notion that SIDS would experience large output fluctuations because they are more energy-intensive and less-diversified than advanced economies. From a policy perspective, this evidence underscores the need for SIDS to continue 
exploring energy diversification opportunities, and highlights the importance of designing outward-oriented economic policies to enhance foreign exchange inflows and encourage resiliency to oil price shocks.

\section{Acknowledgements}

I wish to express my sincere gratitude to David Stern for his useful and insightful comments on drafts of this paper. I would also like to thank the participants at the 2015 International Energy Workshop (IEW) held in Abu Dhabi for their constructive criticisms and feedback on my presentation.

\section{References}

Allegret, J.-P., Mignon, V., \& Sallenave, A. (2015). Oil price shocks and global imbalances: Lessons from a model with trade and financial interdependencies. Economic Modelling, 49, 232-247.

Amuedo-Dorantes, C., Pozo, S., \& Vargas-Silva, C. (2010). Remittances in small island developing states. The Journal of Development Studies, 46(5), 941960.

Anciaes, P. R. (2012). Energy price shocks: Sweet and sour consequences for developing countries. Overseas Development Institute. Retrieved from http: / / www.odi.org / sites / odi.org.uk/files / odi - assets / publications opinion-files/7794.pdf

Bernanke, B. S. (1986). Alternative explanations of the money-income correlation. In Carnegie-rochester conference series on public policy (Vol. 25, pp. 49-99).

Blanchard, O. J. \& Gali, J. (2007). The Macroeconomic Effects of Oil Shocks: Why are the 2000s so different from the 1970s? National Bureau of Economic Research.

Blanchard, O. J. \& Quah, D. (1988). The dynamic effects of aggregate demand and supply disturbances. National Bureau of Economic Research.

Briguglio, L. (1995). Small island developing states and their economic vulnerabilities. World Development, 23(9), 1615-1632. 
Briguglio, L., Cordina, G., \& Kisanga, E. J. (2006). Building the Economic Resilience of Small States. Formatek Publishing for the Islands, Small States Institute of the University of Malta, and the Commonwealth Secretariat, London.

Cashin, P., Mohaddes, K., Raissi, M., \& Raissi, M. (2014). The differential effects of oil demand and supply shocks on the global economy. Energy Economics, $44,113-134$.

Cologni, A. \& Manera, M. (2009). The asymmetric effects of oil shocks on output growth: A Markov-Switching analysis for the G-7 countries. Economic Modelling, 26(1), 1-29.

Darvas, Z. (2012). Real effective exchange rates for 178 countries: a new database.

Dees, S., Mauro, F. d., Pesaran, M. H., \& Smith, L. V. (2007). Exploring the international linkages of the euro area: a global VAR analysis. Journal of Applied Econometrics, 22(1), 1-38.

Denman, R., Denman, J., \& Scott, D. (2012). Challenges and Opportunities for Tourism Development in Small Island Developing States. World Tourism Organization (UNWTO).

Encontre, P. (n.d.). The vulnerability and resilience of small island developing states in the context of globalization. In Natural resources forum (Vol. 23, pp. 261-270). Wiley Online Library.

Feldkircher, M. (2014). A Global macro model for Emerging Europe. Journal of Comparative Economics, 43(3). doi:10.1016/j.jce.2014.09.002

Ferderer, P. (1997). Oil price volatility and the macroeconomy. Journal of Macroeconomics, 18(1), 1-26.

Finn, M. G. (2000). Perfect competition and the effects of energy price increases on economic activity. Journal of Money, Credit and Banking, 32, 400-416.

Ghali, K. \& El-Sakka, M. (2004). Energy use and output growth in Canada: a multivariate cointegration analysis. Energy Economics, 26(2), 225-238.

Golub, S. S. (1983). Oil prices and exchange rates. The Economic Journal, 576-593.

Hamilton, J. D. (2003). What is an oil shock? Journal of econometrics, 113(2), 363-398.

Hamilton, J. D. (2009). Causes and Consequences of the Oil Shock of 2007-08. National Bureau of Economic Research. Retrieved from http: / / www. 
brookings.edu/ /media/Projects/BPEA/Spring\%202009/2009a_bpea_ hamilton.PDF

Helbling, T., Kang, J., Kumhof, M., Muir, D., Pescatori, A., \& Roache, S. (2011). Oil scarcity, growth, and global imbalances.

Hurvich, C. M. \& Tsai, C.-L. (1989). Regression and time series model selection in small samples. Biometrika, 76(2), 297-307.

International Monetary Fund. (2012). World Economic Outlook Database.

Jayaraman, T. K. \& Choong, C.-K. (2009). Growth and oil price: A study of causal relationships in small Pacific Island countries. Energy Policy, 37(6), 21822189. doi:http://dx.doi.org/10.1016/j.enpol.2009.01.025

Johansen, S. (1991). Estimation and hypothesis testing of cointegration vectors in Gaussian vector autoregressive models. Econometrica, 59, 1551-1580.

Johansen, S. (1995). Likelihood-based inference in cointegrated vector autoregressive models. Oxford University Press.

Kilian, L. (2008). The economic effects of energy price shocks. Journal of Economic Literature, 46, 871-909.

Kilian, L. (2009). Not all oil price shocks are alike: Disentangling demand and supply shocks in the crude oil market. American Economic Review, 99(3), 1053-1069.

Kim, H. (2013). Generalized impulse response analysis: General or Extreme? EconoQuantum, 10(2), 136-141.

Krugman, P. R. (1983). Oil and the dollar. National Bureau of Economic Research Cambridge, Mass., USA.

Leybourne, S., Kim, T.-H., \& Newbold, P. (2005). Examination of some more powerful modifications of the Dickey-Fuller test. Journal of Time Series Analysis, 26(3), 355-369.

Lippi, F. \& Nobili, A. (2008). Oil and the macroeconomy: A structural VAR analysis with sign restrictions. Centre for Economic Policy Research.

Lutkepohl, H., Saikkonen, P., \& Trenkler, C. (2001). Maximum eigenvalue versus trace tests for the cointegrating rank of a VAR process. The Econometrics Journal, 287-310.

Mohaddes, K., Raissi, M., \& Raissi, M. (2012). The global impact of the systemic economies and MENA business cycles. International Monetary Fund. 
Mork, K. A. (1989). Oil and the macroeconomy when prices go up and down: an extension of Hamilton's results. Journal of Political Economy, 97(3), 740744.

Park, H. J. \& Fuller, W. A. (1995). Alternative estimators and unit root tests for the autoregressive process. Journal of Time Series Analysis, 16(4), 415-429.

Peersman, G. \& Van Robays, I. (2012). Cross-country differences in the effects of oil shocks. Energy Economics, 34(5), 1532-1547.

Pesaran, M. H. (2004). General diagnostic tests for cross section dependence in panels. USC Dornsife Institute for New Economic Thinking. Retrieved from http://papers.ssrn.com/sol3/papers.cfm?abstract_id $=572504$

Pesaran, M. H., Schuermann, T., \& Weiner, S. M. (2004). Modeling regional interdependencies using a global error-correcting macroeconometric model. Journal of Business E Economic Statistics, 22(2), 129-162.

Rasche, R. H. \& Tatom, J. A. (1977). Energy resources and potential GNP. Federal Reserve Bank of St. Louis Review, (June 1977).

Rasmussen, T. N. \& Roitman, A. (2011). Oil shocks in a global perspective: Are they really that bad? International Monetary Fund. Retrieved from http://www10.iadb.org/intal/intalcdi/PE/2011/08864.pdf

Sims, C. A. (1980). Macroeconomics and Reality. Econometrica, 48(1), 1-48. doi:10.2307/1912017

Sims, C. A. (1986). Are forecasting models usable for policy analysis? Federal Reserve Bank of Minneapolis Quarterly Review, 10(1), 2-16.

Smith, L. \& Galesi, A. (2014). Gvar toolbox 2.0. Retrieved from https://sites. google.com/site/gvarmodelling/gvar-toolbox/download

Tsikata, Y. M., Moreira, E. P., \& Hamilton, P. C. (2009). Accelerating Trade and Integration in the Caribbean: Policy options for sustained growth, job creation, and poverty reduction. World Bank Publications.

UN Department of Economic and Social Affairs. (2015). Sustainable Development Knowledge Platform. United Nations. Retrieved from https: / / sustainabledevelopment.un.org/topics/sids/memberstates

United Nations Economic and Social Commission for Asia and the Pacific. (2003). Asia-Pacific Economies: Sustaining Growth Amidst Uncertainities. Bulletin on Asia-Pacific Perspectives. 
Van Hoa, T. (1992). A multi-equation model of energy consumption in Thailand. International Journal of Energy Research, 16(5), 381-385.

Woodruff, C. \& Zenteno, R. (2007). Migration networks and microenterprises in Mexico. Journal of development economics, 82(2), 509-528.

Yari, M. (2003). Beyond "subsistence affluence": Poverty in Pacific Island countries. Bulletin on Asia-Pacific Perspectives, 4, 41-54. 


\section{Appendices}

\section{A Data Sources and Construction of Variables}

I use data for 26 countries including the US. The list of countries and the respective groups are displayed in Table A.1. Data on real GDP is based on the annual series in national currency extracted from the United Nations National Accounts Main Aggregates database. It is indexed so that real GDP in 2010 equals 100 and then transformed into logarithms.

The real effective exchange rate is from the Bruegel Database and is based on the proposed approach by Darvas (2012). This time series was normalized such that 2010 is 100 and then log-transformed.

The IMF's IFS database is the main source of the consumer price index data. However, Cabo Verde, Guinea-Bissau, Guyana, and Sao Tome and Principe all had missing data which resulted in the entire series for these countries being replaced with data from the World Economic Outlook (WEO) database. This series was subsequently normalized so that $2010=100$ and log-transformed. The final dataset was used to construct the inflation rate $\pi_{i, t}=\ln \left(C P I_{i t}\right)-\ln \left(C P I_{i, t-1}\right)$ where $C P I_{i t}$ is the consumer price index for the $i^{\text {th }}$ country at time $t$.

The series on oil prices is the price of Brent crude oil measured in US dollars per barrel and are taken from the IMF's IFS database. The time series is annual and expressed in logarithms.

For the preliminary exercise in Section 2, I define oil intensity as the value of crude oil consumption relative to GDP in nominal US dollars. I use the value of crude oil imports from the World Economic Outlook (WEO) database as a proxy for oil consumption. This GDP series is also from the same database. Oil share in energy is calculated as oil consumption divided by the total energy (renewable and non-renewable sources). Both are expressed in British Thermal Units and are taken from the US Energy Information Administration (EIA) database. The specific calculation for each relevant variable is shown in Equation A.1. 


$$
\begin{aligned}
& y_{i t}=\ln \left(100 . G D P_{i t} / G D P_{i, 2010}\right) \\
& \text { reer }_{i t}=\ln \left(100 \cdot R_{E E R_{i t}} / R_{E E R_{i, 2010}}\right) \\
& \pi_{i t}=\ln \left(C P I_{i t}\right)-\ln \left(C P I_{i, t-1}\right) \\
& \text { poil }_{t}=\ln \left(100 . \text { nop }_{t} / \text { nop }_{t}\right) \\
& \Delta \text { oil intensity }{ }_{i t}=\ln (\text { oil } / G D P)_{i, 2013}-\ln (\text { oil/GDP })_{i, 1980} \\
& \Delta \text { oil share }{ }_{i t}=\ln (\text { oil/energy })_{i, 2013}-\ln (\text { oil/energy })_{i, 1980}
\end{aligned}
$$

where $C P I_{i t}$ is the consumer price index for the $i^{t h}$ country at time $t$ and nop is the nominal oil price in US dollars. The classification of countries based on oil intensity and oil share is shown in Table A.2.

I use bilateral remittance flows data to compute remittance weights for the foreign variables in the model. Bilateral remittance data for all included SIDS are only available for 2015 and is obtained from the World Bank's Migration and Remittances database. ${ }^{2}$ While I only use data for one year due to availability, remittance weights $w_{i j}$ covering data for multiple years are generally computed as an average over period $T$ to reduce the impact of individual yearly changes using:

$$
w_{i j}=\frac{\sum_{t=1}^{T} R E M_{i j, t}}{\sum_{t=1}^{T} \sum_{j=0}^{N} R E M_{i j, t}}
$$

where $R E M_{i j, t}$ is the remittance of country $i$ with country $j$ during a particular year $t$ for $t=1,2, \ldots, T$. Using weights based on remittances allow us to analyze the importance of the remittance channel in propagating the adverse effects of oil price shocks in SIDS. These estimates are presented in Table A.3.

To construct regional impulse responses, I use purchasing power parity (PPP) converted GDP in current international dollars obtained from the World Bank Development Indicators (WDI) database. In this particular case, I use an average covering 1981 to 2015.

\footnotetext{
${ }^{2}$ This is based on bilateral remittance estimates for 2015 using Migrant Stocks, Host Country Incomes, and Origin Country Incomes (millions of US\$) (April 2016 version).
} 
Table A.1: Countries and Regions in the GVAR model.

\begin{tabular}{|c|c|c|}
\hline \multicolumn{3}{|c|}{ Systemic Economy - U.S.A (US) } \\
\hline Caribbean & Pacific & AIMS \\
\hline The Bahamas (BS) & Fiji (FJ) & Cabo Verde (CV) \\
\hline Barbados (BB) & Papua New Guinea (PG) & Guinea-Bissau (GW) \\
\hline Belize (BZ) & Samoa (WS) & Mauritius (MU) \\
\hline Dominica (DM) & Solomon Islands (SB) & São Tomé and Príncipe (ST) \\
\hline Dominican Republic (DO) & Tonga (TO) & Seychelles (SC) \\
\hline Grenada (GD) & Vanuatu (VU) & \\
\hline \multicolumn{3}{|l|}{ Guyana (GY) } \\
\hline \multicolumn{3}{|l|}{ Haiti (HT) } \\
\hline \multicolumn{3}{|l|}{ Jamaica (JM) } \\
\hline \multicolumn{3}{|l|}{ St. Kitts and Nevis (KN) } \\
\hline \multicolumn{3}{|l|}{ St. Lucia (LC) } \\
\hline \multicolumn{3}{|c|}{ St. Vincent and the Grenadines (VC) } \\
\hline \multicolumn{3}{|c|}{ Suriname (SR) } \\
\hline \multicolumn{3}{|l|}{ Trinidad and Tobago (TT) } \\
\hline
\end{tabular}

Notes: The International Organization for Standardization(ISO) two-letter country codes are also used as official short names. 
Table A.2: Country groupings based on oil share and energy intensity.

\begin{tabular}{ll}
\hline Low energy intensity & \multicolumn{1}{c}{ High oil share } \\
Bahamas & Bahamas \\
Barbados & Barbados \\
Belize & Cabo Verde \\
Cabo Verde & Grenada \\
Dominica & Guinea-Bissau \\
Dominican Republic & Guyana \\
Fiji & Haiti \\
Grenada & Jamaica \\
Guinea-Bissau & St. Kitts and Nevis \\
Haiti & St. Lucia \\
Mauritius & St. Vincent and the Grenadines \\
Papua New Guinea & Sao Tome and Principe \\
St. Kitts and Nevis & Seychelles \\
St. Lucia & Solomon Islands \\
St. Vincent and the Grenadines & Tonga \\
Samoa & Vanuatu \\
Sao Tome and Principe & Low oil share \\
Solomon Islands & Belize \\
Tonga & Dominica \\
Vanuatu & Dominican Republic \\
High energy intensity & Fiji \\
Guyana & Mauritius \\
Jamaica & Papua New Guinea \\
Seychelles & Samoa \\
Suriname & Suriname \\
Trinidad and Tobago & Trinidad and Tobago \\
\hline
\end{tabular}

Notes: The classification is based on 2011 - the most recent year for which data are available for all countries. The International Organization for Standardization(ISO) two-letter country codes are also used as official short names. 


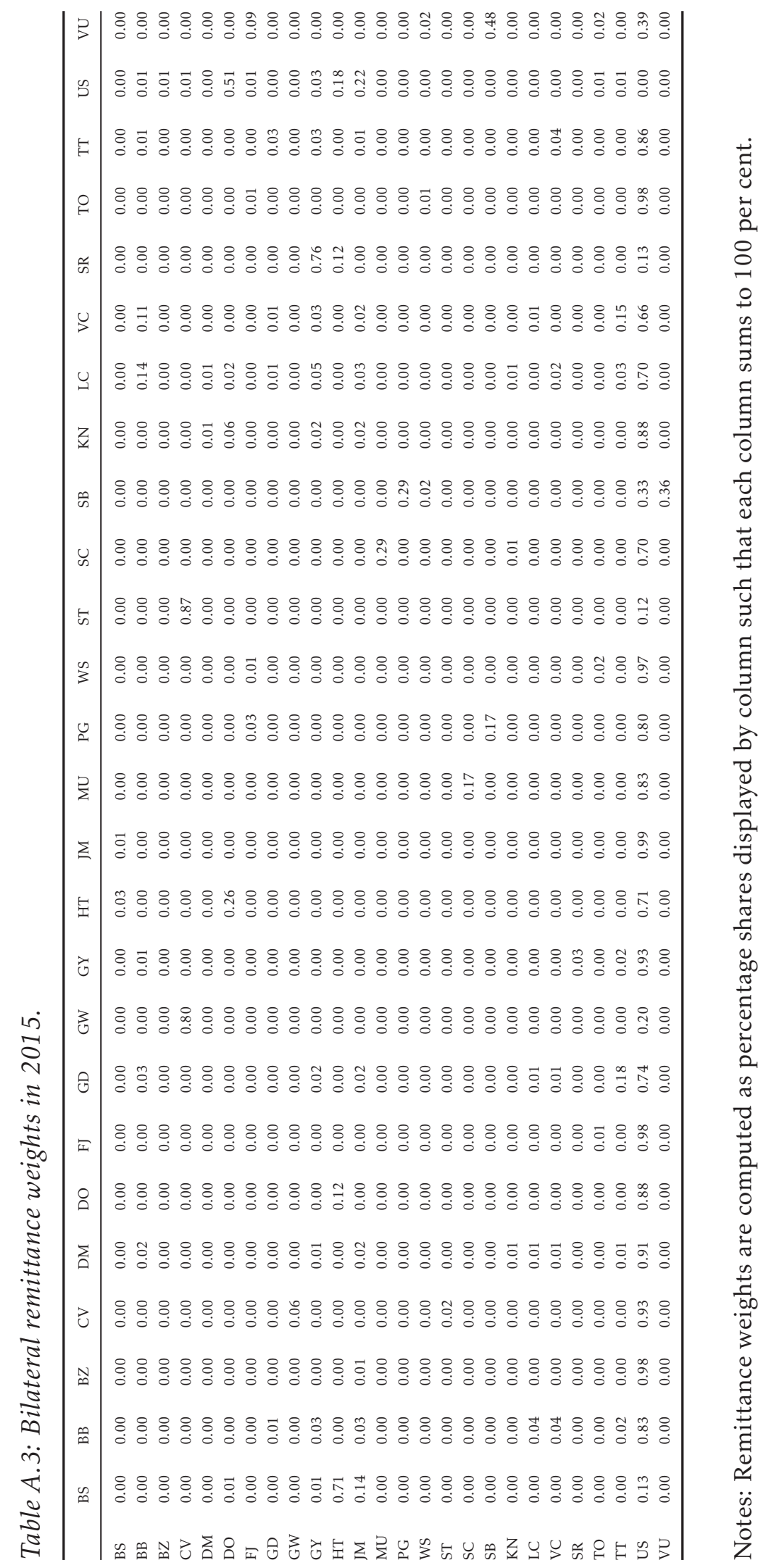




\section{B Model specification and diagnostics}

The specific form of individual country models and the US economy are shown in Appendix B.1.

Table B.1: Variable Specification of the Country-specific VARX Models

\begin{tabular}{lccc}
\hline \multicolumn{2}{c}{ SIDS Individual Models } & \multicolumn{2}{c}{ US Model } \\
\hline Domestic & Foreign & Domestic & Foreign \\
\hline$y_{i t}$ & $y_{i t}^{*}$ & $y_{i t}$ & $y_{i t}^{*}$ \\
$\pi_{i t}$ & $\pi_{i t}^{*}$ & $\pi_{i t}$ & $\pi_{i t}^{*}$ \\
reer $_{i t}$ & - & - & reer $_{i t}^{*}$ \\
- & poil $_{t}$ & poil $_{t}$ & - \\
\hline
\end{tabular}

I also outline test results related to the integration properties of the variables, assess lag structure and cointegration rank statistics, check the weak exogeneity assumption and examine the stability of the individual models over time.

To test the integration properties of the variables in the system I utilize the weighted symmetric estimation of ADF type regressions proposed by Park and Fuller (1995) (ADF-WS) since it is believed to have higher statistical power than the standard ADF test (see Leybourne, Kim, and Newbold (2005)). According to the evidence presented in Table B.2, inflation appears to be an $I(1)$ variable. Real output is also stationary in most countries. The ADF-WS test also shows that the real effective exchange rate was stationary in all countries. The results indicate that in addition to the country-specific variables, most variables are generally $I(1)$ thus supporting their inclusion in the $V A R X^{*}$ structure.

Tests for the optimal order $p_{i}$ of the domestic variables $x_{i}$ are conducted using the Schwarz Bayesian criterion (SBC), which may be more appropriate for small sample size problems as it typically chooses a lower lag length than the Akaike Information criterion (AIC). Many researchers have shown that AIC often shows a tendency to overfit models in small samples (see, for example, Hurvich and Tsai (1989)). Under the constraints imposed by data limitations, I follow Dees et al. (2007) and others, and set $p_{i}=2$. For the same reason I set the number of lags of the foreign-specific variables $x_{i}^{*}$ to one (see Table B.3).

Having tested the integration properties of the variables, it is now possible 
to determine the number of long-run relations for each country (Johansen, 1991, 1995). I use the case where unrestricted constants and restricted trend coefficients (Case $I V$ ) are included in cointegrating VAR models with exogenous I(1) variables. The rank selections are conducted at the 95 per cent critical value level and are based on the trace statistic which is known to have a better small sample power compared to the maximal eigenvalue statistic (Lutkepohl, Saikkonen, \& Trenkler, 2001). A cointegration rank of one was found in most countries and two for most of the others (see Table B.3). Samoa was the only country in which full rank was observed though the domestic variables appear to have a unit root. This apparent contradiction may be due to the low power of the cointegration test stemming from the small sample size.

To ensure that there are no long-run feedback from individual country models to the weighted sum of other counterparts, I test the weak exogeneity assumption of the foreign-specific and common global variables as described in Dees et al. (2007). To be specific, I run the following regression and test the joint significance of the estimated error-correction terms under the null of weak exogeneity for each $l^{\text {th }}$ element of $x_{i t}^{*}$ :

$$
\Delta x_{i t, l}^{*}=\mu_{i l}+\sum_{j=1}^{r_{i}} \gamma_{i j, l} E C M_{i, t-1}^{j}+\sum_{k=1}^{p_{i}} \varphi_{i k, l} \Delta x_{i, t-k}+\sum_{m=1}^{q_{i}} \vartheta_{i m, l} \Delta \tilde{x}_{i, t-m}^{*}+\varepsilon_{i t, l}
$$

where $E C M_{i, t-1}^{j}$ is the estimated error correction term with $j=1,2, \ldots, r_{i}$ and $r_{i}$ is the cointegrating rank found for the $i^{\text {th }}$ country model. The set of foreign-specific and global variables in first differences is given by $\Delta \tilde{x}_{i t}^{*}=\left(\Delta x_{i t}^{*}, \Delta \text { reer }_{i t}^{*}, \Delta \text { poil }_{t}\right)^{\prime}$ for country $i=1,2, \ldots, N$. The $\Delta r e e r_{i t}^{*}$ term is implicit in $\Delta x_{i t}^{*}$ for the US model. The F-test overwhelmingly supports non-rejection of the null for all variables except for foreign inflation in Cabo Verde. These results are presented in Table B.4.

Prior to analysis of the impulse responses, I examine the GVAR's eigenvalues to ensure that the model displays dynamic stability. According to Pesaran (2004), this requires that the eigenvalues be either on or inside the unit circle. As evidenced in Table B.5, all 156 eigenvalues of the GVAR fall on or within the unit circle suggesting that the estimated model is dynamically stable. The model has 42 eigenvalues equal to unity, which corresponds to the number of unit roots 
in the model, with the remaining 114 eigenvalues having moduli all less than unity. 


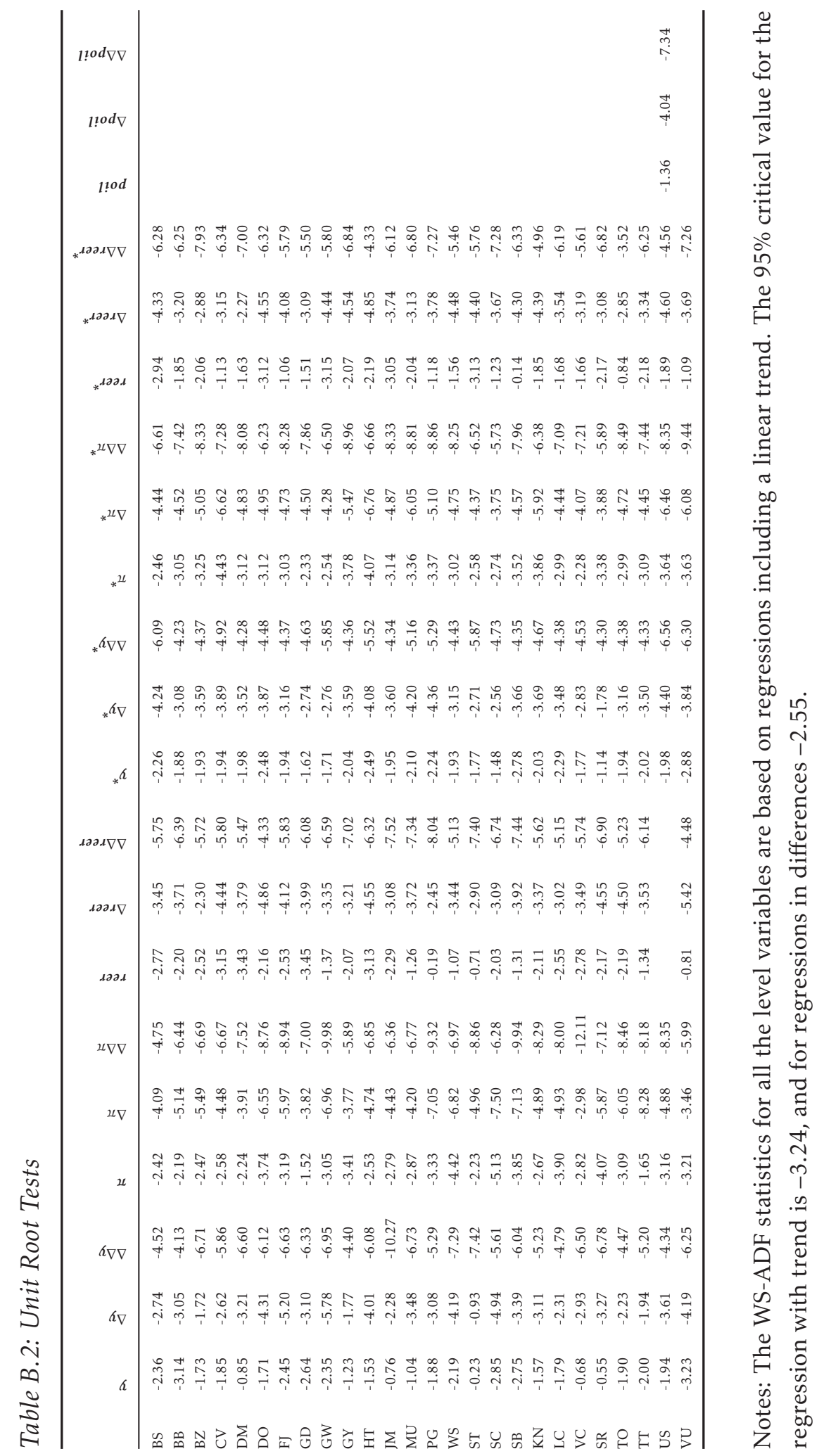


Table B.3: VARX Order and Number of Cointegration Relations in Individual Models.

\begin{tabular}{|c|c|c|c|}
\hline Country & $\mathbf{p}$ & $\mathbf{q}$ & \# Cointegrating Relations \\
\hline Bahamas & 1 & 1 & 1 \\
\hline Barbados & 1 & 1 & 2 \\
\hline Belize & 1 & 1 & 2 \\
\hline Cabo Verde & 1 & 1 & 2 \\
\hline Dominica & 1 & 1 & 1 \\
\hline Dominican Republic & 1 & 1 & 2 \\
\hline Fiji & 1 & 1 & 2 \\
\hline Grenada & 1 & 1 & 1 \\
\hline Guinea-Bissau & 1 & 1 & 2 \\
\hline Guyana & 1 & 1 & 2 \\
\hline Haiti & 1 & 1 & 1 \\
\hline Jamaica & 2 & 1 & 1 \\
\hline Mauritius & 1 & 1 & 1 \\
\hline Papua New Guinea & 2 & 1 & 1 \\
\hline Samoa & 1 & 1 & 3 \\
\hline Sao Tome and Principe & 1 & 1 & 1 \\
\hline Seychelles & 1 & 1 & 1 \\
\hline Solomon Islands & 1 & 1 & 1 \\
\hline St. Kitts and Nevis & 1 & 1 & 2 \\
\hline St. Lucia & 1 & 1 & 1 \\
\hline St. Vincent and the Grenadines & 2 & 1 & 1 \\
\hline Suriname & 1 & 1 & 1 \\
\hline Tonga & 2 & 1 & 1 \\
\hline Trinidad and Tobago & 1 & 1 & 1 \\
\hline United States & 1 & 1 & 1 \\
\hline Vanuatu & 2 & 1 & 1 \\
\hline
\end{tabular}


Table B.4: Test for Weak Exogeneity of Country-specific Foreign Variables and Global Variable at the 5\% Significance Level using F-statistics.

\begin{tabular}{|c|c|c|c|c|c|c|}
\hline Country & $\mathrm{F}$ - test & Fcrit $_{0.05}$ & $y^{*}$ & $\pi^{*}$ & reer $^{*}$ & poil \\
\hline Bahamas & $F(1,23)$ & 4.28 & 0.05 & 0.24 & & 0.08 \\
\hline Barbados & $\mathrm{F}(2,22)$ & 3.44 & 0.23 & 0.07 & & 1.51 \\
\hline Belize & $\mathrm{F}(2,22)$ & 3.44 & 0.89 & 0.66 & & 0.63 \\
\hline Cabo Verde & $F(2,22)$ & 3.44 & 1.89 & 3.62 & & 3.16 \\
\hline Dominica & $\mathrm{F}(1,23)$ & 4.28 & 0.45 & 0.18 & & 0.35 \\
\hline Dominican Republic & $\mathrm{F}(2,22)$ & 3.44 & 0.25 & 0.02 & & 0.12 \\
\hline Fiji & $F(2,22)$ & 3.44 & 0.16 & 0.35 & & 0.44 \\
\hline Grenada & $\mathrm{F}(1,23)$ & 4.28 & 0.12 & 0.20 & & 0.68 \\
\hline Guinea-Bissau & $F(2,22)$ & 3.44 & 0.12 & 0.09 & & 0.18 \\
\hline Guyana & $\mathrm{F}(2,22)$ & 3.44 & 1.24 & 2.29 & & 2.04 \\
\hline Haiti & $F(1,23)$ & 4.28 & 0.03 & 1.52 & & 0.11 \\
\hline Jamaica & $\mathrm{F}(1,23)$ & 4.28 & 0.96 & 1.49 & & 2.75 \\
\hline Mauritius & $\mathrm{F}(1,23)$ & 4.28 & 0.12 & 2.07 & & 2.83 \\
\hline Papua New Guinea & $\mathrm{F}(1,23)$ & 4.28 & 0.56 & 2.89 & & 0.26 \\
\hline Samoa & $\mathrm{F}(3,21)$ & 3.07 & 1.13 & 1.10 & & 1.17 \\
\hline Sao Tome and Principe & $\mathrm{F}(1,23)$ & 4.28 & 1.02 & 2.86 & & 0.09 \\
\hline Seychelles & $\mathrm{F}(1,23)$ & 4.28 & 0.14 & 0.25 & & 1.49 \\
\hline Solomon Islands & $\mathrm{F}(1,23)$ & 4.28 & 0.16 & 0.05 & & 0.18 \\
\hline St. Kitts and Nevis & $\mathrm{F}(2,22)$ & 3.44 & 2.68 & 0.19 & & 2.99 \\
\hline St. Lucia & $\mathrm{F}(1,23)$ & 4.28 & 0.16 & 0.15 & & 0.01 \\
\hline St. Vincent and the Grenadines & $\mathrm{F}(1,23)$ & 4.28 & 1.64 & 4.02 & & 0.21 \\
\hline Suriname & $\mathrm{F}(1,23)$ & 4.28 & 0.08 & 0.24 & & 0.07 \\
\hline Tonga & $\mathrm{F}(1,23)$ & 4.28 & 0.56 & 0.72 & & 0.04 \\
\hline Trinidad and Tobago & $F(1,23)$ & 4.28 & 1.12 & 0.04 & & 0.01 \\
\hline United States & $\mathrm{F}(1,23)$ & 4.28 & 0.02 & 0.00 & 0.03 & \\
\hline Vanuatu & $\mathrm{F}(1,23)$ & 4.28 & 2.77 & 3.07 & & 0.27 \\
\hline
\end{tabular}


Table B.5: Eigenvalues and Moduli of the GVAR Model in Descending Order.

\begin{tabular}{|c|c|c|c|c|c|}
\hline Eigenvalues & Moduli & Eigenvalues & Moduli & Eigenvalues & Moduli \\
\hline 1 & 1 & -0.12 & 0.50 & 0 & 0 \\
\hline 1 & 1 & 0.36 & 0.49 & 0 & 0 \\
\hline 1 & 1 & -0.10 & 0.47 & 0 & 0 \\
\hline 1 & 1 & 0.63 & 0.47 & 0 & 0 \\
\hline 1 & 1 & -0.37 & 0.36 & 0 & 0 \\
\hline 1 & 1 & 0.43 & 0.33 & 0 & 0 \\
\hline 1 & 1 & -0.17 & 0.33 & 0 & 0 \\
\hline 1 & 1 & 0.25 & 0.30 & 0 & 0 \\
\hline 1 & 1 & -0.01 & 0.30 & 0 & 0 \\
\hline 1 & 1 & 0.14 & 0.28 & 0 & 0 \\
\hline 1 & 1 & 0.10 & 0.28 & 0 & 0 \\
\hline 1 & 1 & 0.76 & 0.27 & 0 & 0 \\
\hline 1 & 1 & -0.56 & 0.26 & 0 & 0 \\
\hline 1 & 1 & 0.05 & 0.26 & 0 & 0 \\
\hline 1 & 1 & 0 & 0.23 & 0 & 0 \\
\hline 1 & 1 & 0 & 0.20 & 0.52 & 0 \\
\hline 1 & 1 & 0 & 0.20 & -0.54 & 0 \\
\hline 1 & 1 & 0 & 0.20 & -0.05 & 0 \\
\hline 1 & 1 & 0 & 0.20 & 0.12 & 0 \\
\hline 1 & 1 & 0 & 0.18 & -0.26 & 0 \\
\hline 1 & 1 & 0 & 0.17 & -0.07 & 0 \\
\hline 1 & 1 & 0 & 0.17 & -0.09 & 0 \\
\hline 1 & 1 & 0 & 0.16 & 0.56 & 0 \\
\hline 1 & 1 & 0 & 0.16 & -0.76 & 0 \\
\hline 1 & 1 & 0 & 0.15 & -0.14 & 0 \\
\hline 1 & 1 & 0 & 0.12 & -0.18 & 0 \\
\hline 1 & 1 & 0 & 0.12 & -0.18 & 0 \\
\hline 1 & 1 & 0 & 0.09 & -0.27 & 0 \\
\hline 1 & 1 & 0 & 0.07 & -0.36 & 0 \\
\hline 1 & 1 & 0 & 0.05 & -0.28 & 0 \\
\hline
\end{tabular}


Table B.5 - Continued

\begin{tabular}{|c|c|c|c|c|c|}
\hline Eigenvalues & Moduli & Eigenvalues & Moduli & Eigenvalues & Moduli \\
\hline 1 & 1 & 0 & 0.05 & -0.60 & 0 \\
\hline 1 & 1 & 0 & 0 & -0.50 & 0 \\
\hline 1 & 1 & 0 & 0 & & \\
\hline 1 & 1 & 0 & 0 & & \\
\hline 1 & 1 & 0 & 0 & & \\
\hline 1 & 1 & 0 & 0 & & \\
\hline 1 & 1 & 0 & 0 & & \\
\hline 1 & 1 & 0 & 0 & & \\
\hline 1 & 1 & 0 & 0 & & \\
\hline 1 & 1 & 0 & 0 & & \\
\hline 1 & 1 & 0 & 0 & & \\
\hline 1 & 1 & 0 & 0 & & \\
\hline 0.82 & 0.82 & 0 & 0 & & \\
\hline 0.80 & 0.80 & 0 & 0 & & \\
\hline 0.73 & 0.73 & 0 & 0 & & \\
\hline 0.72 & 0.72 & 0 & 0 & & \\
\hline 0.63 & 0.67 & 0 & 0 & & \\
\hline 0.60 & 0.67 & 0 & 0 & & \\
\hline 0.57 & 0.67 & 0 & 0 & & \\
\hline 0.56 & 0.67 & 0 & 0 & & \\
\hline 0.49 & 0.67 & 0 & 0 & & \\
\hline 0.94 & 0.67 & 0 & 0 & & \\
\hline-0.06 & 0.66 & 0 & 0 & & \\
\hline 0.35 & 0.66 & 0 & 0 & & \\
\hline 0.25 & 0.63 & 0 & 0 & & \\
\hline 0.23 & 0.60 & 0 & 0 & & \\
\hline 0.82 & 0.57 & 0 & 0 & & \\
\hline-0.48 & 0.56 & 0 & 0 & & \\
\hline 0.15 & 0.53 & 0 & 0 & & \\
\hline 0.27 & 0.53 & 0 & 0 & & \\
\hline-0.01 & 0.52 & 0 & 0 & & \\
\hline
\end{tabular}


Table B.5 - Continued

\begin{tabular}{cccccc}
\hline Eigenvalues & Moduli & Eigenvalues & Moduli & Eigenvalues & Moduli \\
\hline 0.38 & 0.52 & 0 & 0 & \\
\hline
\end{tabular}

\section{Impulse response functions}

\section{C.1 Standard GIRFs}

In using GIRFs no attempt is made to identify shocks to a particular variable or establish a causal relationship among variables. To consider the effects of a global or exogenous variable in the model, Pesaran et al. (2004) suggest that this can be done using a weighted average of variable-specific shocks across all the countries in the model. This involves a shock to the $l^{\text {th }}$ variable in the $i^{\text {th }}$ model and integrating the effects of other shocks using a historically observed distribution of the errors. To see this more clearly, I use the errors obtained from Equation 7 and define the GIRF as:

$$
\operatorname{GIRF}\left(x_{t} ; u_{i l t}, h\right)=E\left(x_{t+h} \mid u_{i l t}=\sqrt{\sigma_{i i, l l}}, I_{t-1}\right)-E\left(x_{t+h} \mid I_{t-1}\right)
$$

where $I_{t-1}$ is the information set at time $t-1, \sigma_{i i, l l}$ is the diagonal element of the variancecovariance matrix $\Sigma_{u}$ corresponding to $l^{\text {th }}$ equation in the $i^{\text {th }}$ country model, and $h$ is the time horizon.

Under the assumption of normality of $u_{t}$, the effect of a one standard error global shock at time $t$ to the $l^{t h}$ variable on the $j^{\text {th }}$ variable at time $t+h$ is given by the $j^{\text {th }}$ element of:

$$
\operatorname{GIRF}\left(x_{t} ; u_{l t}, h\right)=\frac{e_{j}^{\prime} A_{h} G_{0}^{-1} \sum_{u} e_{l}}{\sqrt{e_{j}^{\prime} \sum_{u} e_{l}}} \text { for } h=0,1,2, \ldots ; l, j=1,2, \ldots, k
$$

where $e_{l}=(0,0, \ldots, 0,1,0, \ldots, 0)$ ' is a selection vector with the $l^{\text {th }}$ element being unity.

Considering the price of oil as the global variable and the $l^{\text {th }}$ variable in all $N+1$ countries, its effects can be simulated by simultaneously aggregating to a single shock using weights based on GDP in purchasing power parity dollars and current prices. These weights reflect the relative importance of individual countries in the global model. This data were extracted from the World Development Indicators database and covers 
the period 1981 to 2015.

Despite some criticism by Kim (2013), for example, GIRFs avoid the use of the identifying assumptions of standard orthogonalized impulse response analysis (Sims, 1980). According to Pesaran et al. (2004), the short-run restrictions method by Sims (1986) and Bernanke (1986) and the long-run restrictions approach proposed by Blanchard and Quah (1988) are feasible when only a few variables are included in the VAR. However, when a large number of countries are involved, the structural identification of shocks in the global economy depends on the suitable ordering of the variables within each country as well as of the countries in the GVAR model (Dees et al., 2007).

With $N+1$ countries and $k_{i}$ endogenous variables, a total of $\sum_{i=0}^{N} k_{i}\left(k_{i}-1\right)$ identifying restrictions would be required for the GVAR model. Imposing 156 identifying restrictions would have been an arduous task to accomplish in this study. Hence, without strong prior beliefs and economic theory to guide the ordering of the variables and countries in the GVAR model, Pesaran et al. (2004) recommend the use of GIRFs to describe what happens to changes in a variable following a particular shock without identifying the specific source of those changes.

\section{C.2 Orthogonalised IRFs (OIRFs) using remittance weights}

Apart from being guided by the results of diagnostic tests, a number of assumptions are made in relation to the identification of structural shocks to different variables in the models for each country. In this case we need to select the appropriate order for all countries and variables in the GVAR. The identification approach used follows from the Cholesky decomposition which assumes a recursive ordering with zero-restrictions imposed on the system of linear equations. The recursive structure assumes that some variables do not respond to shocks contemporaneously. The causal ordering is defined in the following way: $x_{i, t}=\left(\right.$ poil $\left._{t}, \pi_{i, t}, y_{i, t}\right)$. Therefore, the orthogonalised impulse response functions originating from Equation 7 are given by:

$$
\operatorname{OIRF}\left(x_{t} ; u_{l t}^{*}, h\right)=e_{j}^{\prime} A_{h} G_{0}^{-1} \mathrm{Q} e_{l} \text { for } h=0,1,2, \ldots ; l, j=1,2, \ldots, k
$$

where $e_{l}=(0,0, \ldots, 0,1,0, \ldots, 0)^{\prime}$ is a selection vector with the $l^{\text {th }}$ element being unity.

Starting with the US model which is placed as the first country-specific model in the GVAR, I assume that the price of oil is contemporaneously exogenous such that innovations in inflation and GDP do not affect oil prices within the same year. An inflation shock hits inflation and GDP immediately but does not change oil price until 
the next period while a GDP shock affects GDP in the current period but does not affect the other variables until the next period.

For all SIDS economies, we have $x_{i, t}=\left(\right.$ reer $\left._{i, t}, \pi_{i, t}, y_{i, t}\right)$ where oil price is treated as globally exogenous to see how the system reacts to shocks to this variable. Golub (1983) and Krugman (1983) argue that higher oil prices will transfer wealth from the oil importers to the oil exporters. Hence, the distortion in the balance of trade is likely to influence the exchange rate. Therefore, I first assume that exchange rate changes feed directly into inflation and GDP. In the second equation, inflation changes influence GDP changes contemporaneously. In the final equation, I assume that changes in GDP are dependent on the inflation rate and exchange rate movements. Singapore is included as the second economy in the GVAR due to its comparatively larger economic size but no attempt is made to order the other countries which I assume to be too small for innovations in those economies to affect each other.

In general, the OIRFs results in Figures C.1 and C. 2 are similar to the results in Figures 4 and 5, respectively. 

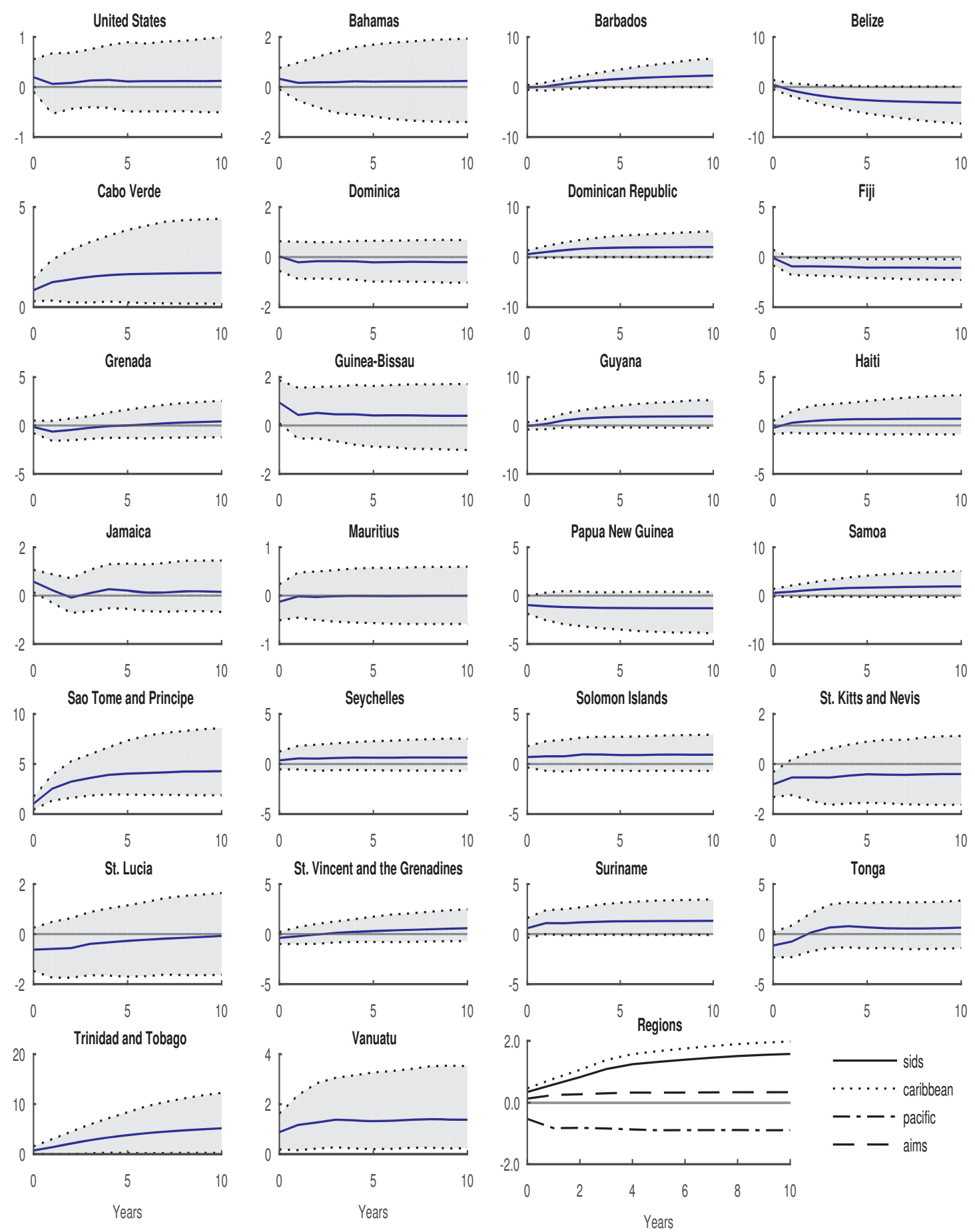

Figure C.1: GDP response in individual SIDS to oil price shock. Results are based on the orthogonalised impulse response function (OIRF). 

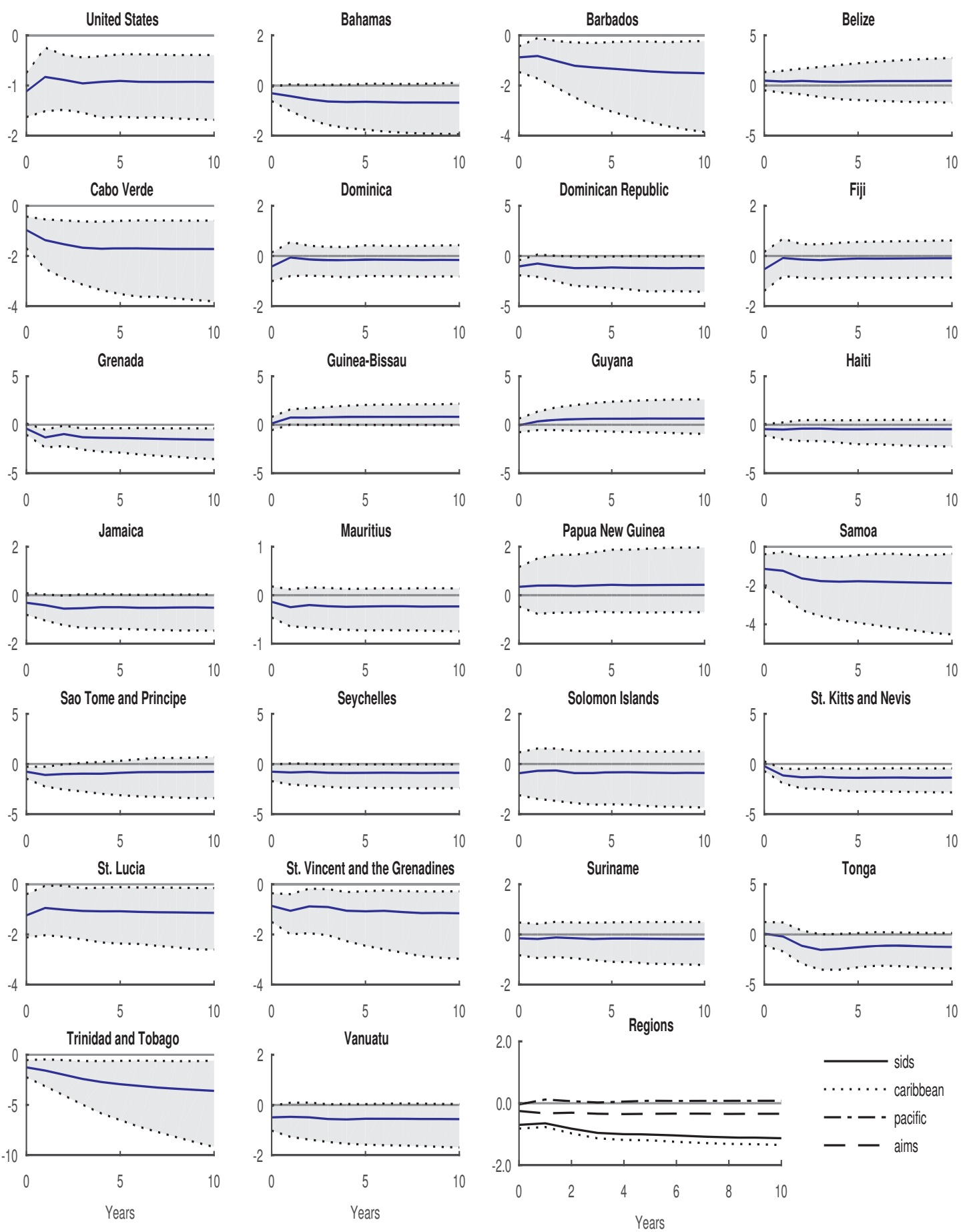

Figure C.2: GDP response in individual SIDS to negative demand shock to US GDP - OIRF. 